\title{
Bibliography of Selected Water-Resources Publications on Nevada by the U.S. Geological Survey, 1885 through 1993
}

By Robin L. Bunch

U.S. GEOLOGICAL SURVEY

Open-File Report 94-53

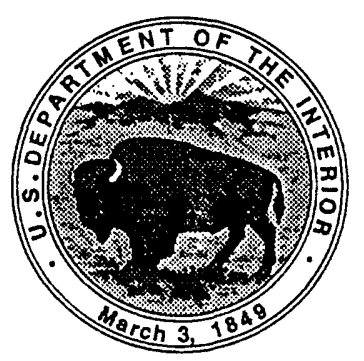

Carson City, Nevada 1994 


\section{U.S. DEPARTMENT OF THE INTERIOR BRUCE BABBITT, Secretary}

U.S. GEOLOGICAL SURVEY

ROBERT M. HIRSCH, Acting Director

Any use of trade names in this publication is for descriptive purposes only and does not Imply endorsement by the U.S. Government.

For additional information write to:

District Chief U.S. Geological Survey 333 West Nye Lane, Room 203 Carson City, NV 89706-0866
Copies of this report can be purchased from:

U.S. Geological Survey Earth Science Information Center Open-File Reports Section Box 25286, MS 517 Denver Federal Center Denver, CO 80225-0046 


\section{CONTENTS}

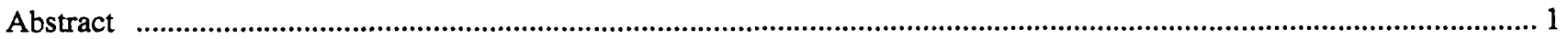

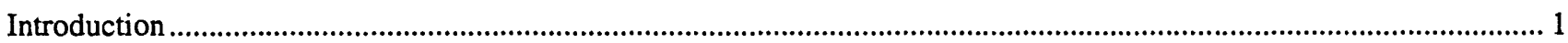

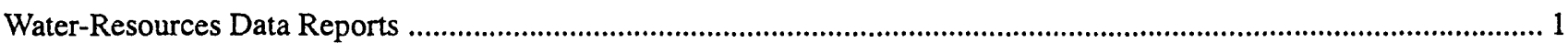

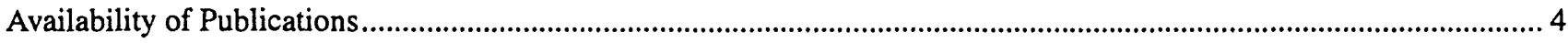

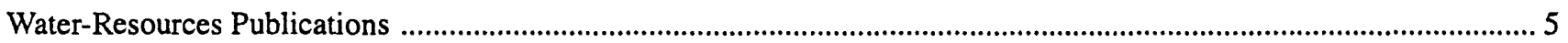

\section{FIGURE}

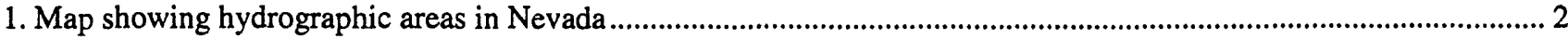




\title{
Bibliography of Selected Water-Resources Publications on Nevada by the U.S. Geological Survey, 1885 through 1993
}

\author{
By Robin L. Bunch
}

\begin{abstract}
References to 607 water-resources publications are listed alphabetically by senior author. Most of the publications were written during 1962-93 by scientists and engineers of the Nevada District, which is part of the Water Resources Division, U.S. Geological Survey. Also included, for historical perspective, are selected earlier reports by Water Resources Division authors that deal with Nevada hydrology. The references include several types of Geological Survey book and map publications, as well as State-series reports, journal articles, abstracts, poster-session displays, and graduate-degree theses.
\end{abstract}

\section{INTRODUCTION}

This bibliography is a compilation of references to 607 publications pertaining to the water resources of Nevada. Most of the listed publications were written during the last three decades by scientists and engineers of the Nevada District, which is a part of the Water Resources Division, U.S. Geological Survey (USGS). Also included, for historical perspective, are selected earlier reports by Water Resources Division authors that deal with Nevada hydrology. This report contains 84 references in addition to those in the bibliography it supersedes (Bunch, 1992).

The compilation herein contains references to reports published from 1885 through December 1993. References are listed alphabetically by senior author. Geographic areas identified within the titles are capitalized in bold type to aid the reader in identifying publications of interest. The hydrographic areas of Nevada are shown in figure 1 as a further aid.
Separate bibliographies are available that list publications written by USGS personnel pertaining to the Yucca Mountain and Nevada Test Site areas of southern Nevada:

Glanzman, V.M., 1991, Bibliography of publications related to the Yucca Mountain Site Characterization Project prepared by U.S. Geological Survey personnel through April 1991: U.S. Geological Survey Open-File Report 91-341, $52 \mathrm{p}$.

Glanzman, V.M., 1992, Bibliography of publications prepared by U.S. Geological Survey personnel under cooperative programs with the U.S. Department of Energy and predecessor agencies, 1957-1991, with emphasis on nuclear testing programs: U.S. Geological Survey Open-File Report 92-502, 83 p.

These reports may be purchased from the Earth Science Information Center (see section "Availability of Publications").

\section{WATER-RESOURCES DATA REPORTS}

Water-resources data were published in Geological Survey Water-Supply Papers until 1970. Data on surface-water quantity were the first to be reported, beginning before 1900 . From 1941 to 1970 , data on surface-water quality were reported annually in separate Water-Supply Papers. The data were reported by water year, which is the 12-month period from October 1 to September 30, designated by the calendar year in which it ends. From 1946 to 1974 , ground-water levels were reported by calendar year in separate WaterSupply Papers. Since water year 1961, water-resources data also have been published in a series of annual reports for Nevada. 


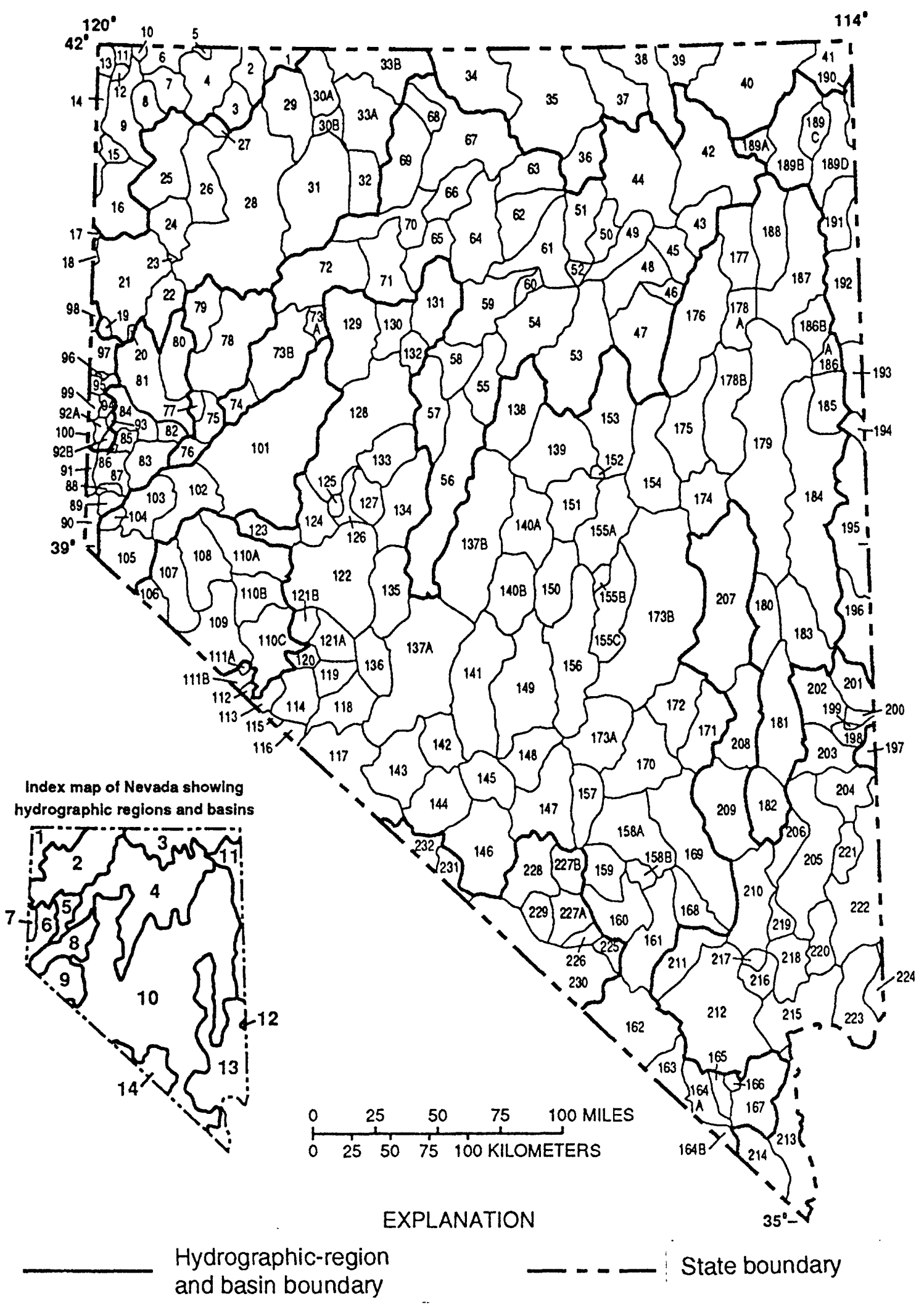

Hydrographic-area

boundary

Figure 1.-Hydrographic areas in Nevada (modified from Rush, 1968a). 
1-NORTHWESTREGION

1. Pueblo V

2. Continenta/ Lake V.

3. Gridley Lake V

4. Virgin V.

5. Sage Hen V.

6. Guano V.

7. Swan Lake V.

8. Massacre Lake V.

9. Long $V$.

10. Macy Fiat

11. Coleman V.

12. Mosquito $V$

13. Wamer $V$.

14. Suprise $V$

15. Boulder V.

16. Duck Lake V.

2-BLACK BOCKDESERT BEGION

17. Pilgrim Fial

18. Painter Fla

19. Dry V.

20. Sano V.

21. Smoke Creek Desert

22. San Emidio Desert

23. Granite Basin

24. Hualapai Flat

25. High Rock Lake V.

26. Mud Meadow

27. Summit Lake V.

28. Pine Foresi V.

30. Kings River $V$.

(A) Rio King Subarea

(B) Sod House Subarea

31. Desert V.

32. Silver State V.

33. Quinn Rlver $V$

(A) Orovada Subarea

(B) McDermitt Subarea

3. SNAKE RIVER BASIN

34. Little Owyhee River Area

35. South Fork Owythee River Ares

36. Independence V.

37. Owyhee River Ares

36. Bruneau River Area

39. Jarbidge River Area

40. Saimon Falls Creek Area

41. Goose Creek Area

4-HUMBOLOT RIVERBASIN

42. Marys River Area

43. Start V. Ares

44. North Fork Ares

45. Lamoille V.

46. South Fork Area

47. Huntington $V$.

48. Dixie Creek - Tenmile Creek Area

49. Elko Segment

50. Susie Creek Asea

51. Maggie Creek Area

52. Marys Creok Ares

53. Pine V.

54. Crescent V.

55. Carico Lake V

56. Upper Reese River $V$

57. Antelope V.

58. Middle Reese River $Y$.

59. Lower Reese River $Y$

60. Whistwind $V$

61. Boulder Flat

62. Rock Creak V.

63. Willow Creek

64. Clovers Area

65. Pumpernickel V.

66. Kelly Creek Area

67. Little Humboldt V.

68. Hardscrabble Ares

69. Paradise V.

70. Winnemucca Segment

71. Grass V.

72. Imlay Area

73. Lovelock V.

(A) Oreana Subarea

74. White Plains

5-WEST CENTRAL REGION

75. Bradys Hol Springs Area

76. Femley Ares

77. Fireball V.

78. Grarite Springs V

79. Kumiva V

\section{6-IRUCKEE RIVERBASIN}

80. Winnemucca Lake $V$.

81. Pyramid Lake V.

82. Dodge Flat

83. Tracy Segment

84. Warm Springs V

85. Spanish Springs V.
86. Sun V

77. Truckee Meadows

88. Pleasant $V$.

89. Washoe $V$

90. Lake Tahoe Basin

91. Truckeo Canyon Segment

\section{BEGION}

02. Lemmon $V$.

(A) Western Part

(B) Esstern Part

93. Antelope V.

94. Bedell Flat

95. Dry V

96. Newcomb Lake V.

97. Honey Lake $V$

98. Skedaddle Creek V.

99. Red Rock V.

100. Cold Spring V.

(A) Long V.

8-CARSON RIVER BASIN

101. Carson Desent

02. Churchill V.

103. Dayton V.

104. Eagle V

105. Carson Valley

9-WALKER RIVEB BASIN

106. Antelope V.

107. Smith V.

108. Mason V.

109. East Walker Ares

110. Walker Lake V.

(A) Schurz Subarea

(B) Lake Subarea

(C) Whisky Flal --Hawthorne Subares

10-CENTRALREGION

111. Alkall V. (Mineral)

(A) Northern Pan

(B) Southern Part

112. Mono $V$

113. Huntoon V.

114. Teels Maren V

115. Adobe V.

118. Queen V.

117. Fish Lake V.

118. Columbus Salt Marsh V

119. Rhodes Satt Marsh V.

120. Garfield Flat

121. Soda Spring V

(A) Eastern Part

(B) Western Pan

122. Gabbs V.

123. Rawhide Flats

124. Falniew V.

125. Stingaree $V$.

126. Cowkick V.

127. Eastgage V. Ares

128. Dixie V.

129. Buena Vista V

130. Pleasant V.

131. Buttalo V

132. Jersey V.

133. Edwards Creek V

134. Smith Creek V.

135. lone V

136. Monte Cristo V.

137. Blo Smoky V.

(A) Tonopah Flat

(B) Northern Part

136. Grass V.

139. Koben V.

140. Monitor $V$

(A) Northern Pan

(B) Southern Par

141. Ralston V.

142. Alkali Spring V. (Esmeralda

143. Clayton

144. Lida V.

145. Stonewall Flats

146. Sarcobatus Fla!

147. Gold Fia!

148. Cactus Fla!

149. Stone Cabin V.

150. Little FIsh Lake V.

151. Antelope V. (Eureka \& Nye)

152. Slevens Basin

153. Dismond V

154. Newark V.

155. Little Smoky V.

(A) Northem Part

(B) Central Part

(C) Southem Part

156. Hol Creek V.

157. Kawlch V.
158. Emigrant V.

(A) Groom Lake V.

(B) Papoose Lake V.
159. Yucse Flat

160. Frenctiman Flat

161. Indian Springs $V$.

162. Pahrump V.

163. Mesquilie V. (Sandy V.)

164. Ivanpah V.

(A) Northem Part

(B) Southern Part

165. Jean Lake V.

166. Hidden V. (South)

167. Eldorado $V$.

168. Three Lakes V. (Northern Part)

169. Tikapoo V. (Tickaboo V.)

(A) Northern Part

70. Ponoyer V. (Sand Spring V.)

171. Cosi V.

172. Garden V.

173. Railroad V.

(A) Southern Part

(B) Nonthern Pan

174. Jakes V.

175. Long V.

176. Ruby V.

177. Clover V.

178. Butte V.

(A) Nonthem Pant (Round V.)

(B) Southem Part

179. Sleptoe V.

180. Cave V.

181. Dry Lake V.

182. Delamar V.

183. Lake V.

184. Spring V.

185. TippetI

188. Antelope V. (White Pine \& Elko)

(A) Southern Part

(B) Northem Part

188. Independence V. (Pequop V.)

11-GREAT SALTLAKE BASIN

189. Thousand Springs $V$.

(A) Herrill Siding--Brush Creek Ares

(B) Toano-Rock Spring Area

(C) Rocky Butto Area

(D) Montello-Crittenden Creek Ares (Montello V.)

190. Grouse Creek

191. Pliot Creek V.

192. Great Salt Lake Desert

193. Deep Creek V.

194. Pleasant V.

195. Snake V.

196. Hamlin V.

\section{2-ESCALANTE DESER}

197. Escalante Desert

198. Dry V.

199. Pose V.

201. Spring V.

202. Patterson V.

203. Panace V.

204. Clover V.

205. Lower Meadow Valley Wash

206. Kane Springs V.

207. White Rlver V.

208. Pahroc V.

209. Pahranagat V.

210. Coyote Spring V.

211. Three Lakes V. (Southern Part)

212. Las Vegas $V$.

213. Colorado

214. Piute V.

215. Black Mountains Ares

216. Gamet V. (Dry Lake V.)*

217. Hidden V. (North)

218. California Wash

219. Muddy River Springs Area (Upper Moapa V.)

220. Lower Moapa V.

222. Virgin River $V$.

223. Gold Butte Ares

224. Greasewood Basin

"Noncontributing part of the Colorado River basin

14-DEATH VALLEYBASIN

225. Mercury $V$

226. Rock V.

227. Fortymile Canyon

(A) Jackass Flats

(B) Buckboard Mesa

228. Oasis V.

229. Crater Fia

230. Amargosa Desert

231. Grapevine Canyon

232. Oriental Wash 
Compilations of data on surface-water quantity in Nevada for water years through 1970 are summarized geographically by "part number" in the following Water-Supply Papers (WSP):

\begin{tabular}{llll}
\hline & \multicolumn{3}{c}{ WSP number } \\
\cline { 2 - 4 } Water year & Part 9 $^{\mathrm{a}}$ & Part 10 & Part 13 \\
\hline Through 1950 & 1313 & 1314 & 1317 \\
$1951-60$ & 1733 & 1734 & 1737 \\
$1961-65$ & 1926 & 1927 & 1934 \\
$1966-70$ & 2126 & 2127 & 2134 \\
\hline \multicolumn{4}{c}{${ }^{\text {a }}$ Colorado River basin } \\
b The Great Basin \\
c Snake River basin \\
\end{tabular}

Information on surface-water quality in Nevada for water years 1941-70 is given in the following Water-Supply Papers:

\begin{tabular}{cccccc}
\hline $\begin{array}{c}\text { Water } \\
\text { year }\end{array}$ & $\begin{array}{c}\text { WSP } \\
\text { number }\end{array}$ & $\begin{array}{c}\text { Water } \\
\text { year }\end{array}$ & $\begin{array}{c}\text { WSP } \\
\text { number }\end{array}$ & $\begin{array}{c}\text { Water } \\
\text { year }\end{array}$ & $\begin{array}{c}\text { WSP } \\
\text { number }\end{array}$ \\
\hline 1941 & 942 & 1951 & 1200 & 1961 & 1885 \\
1942 & 950 & 1952 & 1253 & 1962 & 1945 \\
1943 & 970 & 1953 & 1293 & 1963 & 1951 \\
1944 & 1022 & 1954 & 1353 & 1964 & 1958 \\
1945 & 1030 & 1955 & 1403 & 1965 & 1965 \\
1946 & 1050 & 1956 & 1453 & 1966 & 1995 \\
1947 & 1102 & 1957 & 1523 & 1967 & 2015 \\
1948 & 1133 & 1958 & 1574 & 1968 & 2098 \\
1949 & 1163 & 1959 & 1645 & 1969 & 2148 \\
1950 & 1189 & 1960 & 1745 & 1970 & 2158 \\
\hline
\end{tabular}

Information on ground-water levels in Nevada for calendar years 1946-74 is given in the following Water-Supply Papers:

\begin{tabular}{llll}
\hline $\begin{array}{c}\text { Calendar } \\
\text { year }\end{array}$ & $\begin{array}{c}\text { WSP } \\
\text { number }\end{array}$ & $\begin{array}{c}\text { Calendar } \\
\text { year }\end{array}$ & $\begin{array}{c}\text { WSP } \\
\text { number }\end{array}$ \\
\hline $1946-50$ & 1170 & 1955 & 1409 \\
1951 & 1196 & $1956-60$ & 1770 \\
1952 & 1226 & $1961-65$ & 1855 \\
1953 & 1270 & $1966-70$ & 2010 \\
1954 & 1326 & $1971-74$ & 2162 \\
\hline
\end{tabular}

Surface-water records have been released in U.S. Geological Survey annual data reports for Nevada since water year 1961. Data on surface-water quality have been included in the annual reports since 1965; data on ground-water levels have been included since 1975; and data on ground-water quality have been included since 1976. These annual data reports are:
U.S. Geological Survey, 1962-65, Surface water records of Nevada, 1961-64: Carson City, Nev., U.S. Geo- logical Survey water-data reports (published annu- ally).

U.S. Geological Survey, 1966-75, Water resources data for Nevada, 1965-74: Carson City, Nev., U.S. Geological Survey water-data reports (published annually).

U.S. Geological Survey, 1976-93, Water resources data, Nevada, water years 1975-92: U.S. Geological Survey Water-Data Reports NV-75-1 to NV-92-1 (published annually).

\section{AVAILABILITY OF PUBLICATIONS}

This bibliography contains references to publications of many organizations in addition to those of the U.S. Geological Survey. Inspection copies of many USGS reports, including unnumbered open-file reports, are available at the Nevada District office in Carson City. Publications of organizations other than the U.S. Geological Survey may be obtained from the appropriate agency or publishing organization. Some publications are out of print and available only from libraries, such as the Nevada State Library and the University of Nevada Libraries. Graduate-degree theses should be borrowed from the author or university cited in the reference.

\section{U.S. Geological Survey water-resources investigations and open-file reports are available from: \\ Earth Science Information Center \\ U.S. Geological Survey, Open-File Reports Section Box 25286, MS 517, Federal Center \\ Denver, CO 80225-0046}

(303) $236-7476$ 
U.S. Geological Survey book and map publications are available from:

\author{
Western Distribution Branch \\ U.S. Geological Survey \\ Box 25286, Federal Center \\ Denver, CO 80225-0046 \\ (303) $236-7477$
}

Prepayment is required for books and maps. When ordering either books or maps, give the series designation, number, and title. For example: WaterSupply Paper 2313, Streamflow, sediment transport, and nutrient transport at Incline Village, Lake Tahoe, Nevada, 1970-73.

Inquiries about the investigations described in the publications listed herein may be addressed to:

Public Information Assistant

U.S. Geological Survey, WRD

333 W. Nye Lane, Room 203

Carson City, NV 89706-0866

Telephone: (702) 887-7649

New publications of the U.S. Geological Survey-for the Nevada District as well as other areasare listed in two series:

New Publications of the Geological Survey, which is published monthly and available by free subscription from the U.S. Geological Survey, 582

National Center, Reston, VA 22092; and

Publications of the Geological Survey, which is published annually and may be ordered from the Earth Science Information Center, Open-File Reports Section, Box 25286, Federal Center, Denver, CO 80225 0046.

\section{WATER-RESOURCES PUBLICATIONS}

[Note: Asterisk indicates citation added since previous bibliography (Bunch, 1992).]

Andraski, B.J., 1989, Physical properties of trench backfill at a simulated burial site for low-level radioactive waste near BEATTY, NV [abs.]: 80th Annual Meeting, American Society of Agronomy, Anaheim, Calif., December 1988, Program of Agronomy Abstracts, v. 80, p. 178 .
Andraski, B.J., 1990, Rubber-balloon and drive-core sampling for determining bulk density of an alluvial desert soil [abs.]: Agronomy Abstracts, American Society of Agronomy, 1990 Annual Meetings, San Antonio, Texas, October 1990, p. 208.

Andraski, B.J., 1990, Soil-water movement at a simulated burial site for low-level radioactive waste near BEATTY, Nevada-First year results [abs.], in Nevada decision point-Which water course to the future?: Annual Conference, Nevada Water Resources Association, Las Vegas, Nev., February 1990, Program Information and Abstracts, unpaginated.

Andraski, B.J., 1990, Water movement and trench stability at a simulated arid burial site for low-level radioactive waste near BEATTY, Nevada: La Grange Park, Ill., American Nuclear Society, Nuclear Waste Isolation in the Unsaturated Zone, Las Vegas, Nev., September 1989, Proceedings, p. 166-173.

Andraski, B.J., 1991, Balloon and core sampling for determining bulk density of an alluvial desert soil: Soil Science Society of America Journal, v. 55, p. 11881190.

Andraski, B.J., 1991, Soil-water regime at a low-level radioactive waste site, AMARGOSA DESERT, Nevada: Characterization of Transport Phenomena in the Vadose Zone, A Workshop Sponsored by Soil Science Society of America and American Geophysical Union, Tucson, University of Arizona, April 1991, Proceedings, p. 2-3.

Andraski, B.J., 1991, Vegetation and land-disturbance effects on recharge potential, AMARGOSA DESERT, Nevada [abs.]: Agronomy Abstracts, American Society of Agronomy, 1991 Annual Meetings, Denver, Colo., October 1991, p. 212.

*Andraski, B.J., 1992, Water movement through soil at a low-level radioactive-waste site in the AMARGOSA DESERT: U.S. Geological Survey Yearbook, Fiscal Year 1991, p. 73-75.

*Andraski, B.J., Fischer, J.M., and Prudic, D.E., 1991, BEATTY, Nevada, in Trask, N.J., and Stevens, P.R., U.S. Geological Survey Research in radioactive waste disposal-Fiscal years 1986-90: U.S. Geological Survey Water-Resources Investigations Report 914084, p. 34-40. 
*Andraski, B.J., and Lowery, B., 1992, Erosion effects on soil water storage, plant water uptake, and corn growth: Soil Science Society of America Journal, v. 56, no. 6, p. 1911-1919.

Arteaga, F.E., 1978, Appraisal of water resources in the Fort McDermitt Indian Reservation, HUMBOLDT COUNTY, Nevada: U.S. Geological Survey OpenFile Report 78-139, $50 \mathrm{p}$.

Arteaga, F.E., 1982, Mathematical model analysis of the EAGLE VALLEY ground-water basin, west-central Nevada: U.S. Geological Survey Open-File Report $80-1224,55 \mathrm{p}$.

Arteaga, F.E., 1990, Cost effectiveness of the stream-gaging program in NEVADA: U.S. Geological Survey Water-Resources Investigations Report 87-4213, 68 p.

Arteaga, F.E., Brass, J.A., and Ambrosia, V.G., 1985, Use of Landsat data in estimating evapotranspiration rates of Sierra Nevada vegetation in WASHOE VALLEY, Nevada: Symposium on Tropical Hydrology, American Water Resources Association, and Second Caribbean Islands Water Resources Congress, San Juan, Puerto Rico, May 1985, Poster-Session Display.

Arteaga, F.E., and Durbin, T.J., 1978 [1979], Development of a relation for steady-state pumping rate for EAGLE VALLEY ground-water basin, Nevada: U.S. Geological Survey Open-File Report 79-261, 44 p.

Arteaga, F.E., and Nichols, W.D., 1984, Hydrology of WASHOE VALLEY, Washoe County, Nevada: U.S. Geological Survey Open-File Report 84-465, 29 p.

Arteaga, F.E., Savard, C.S., Johnson, M.E., and Stone, J.C., 1991, Hydrogeologic data from selected wells and test holes in and adjacent to the NEVADA TEST SITE, Nye County, Nevada, through 1986: U.S. Geological Survey Open-File Report 87-536, 23 p.

*August, M.H., Jacoboni, J.M., Jeton, A.E., Parker, R.S., Pupacko, Alex, Ruddy, B.C., Smith, J.L., and Redmond, K.T., 1992, Hydrologic and climatic data bases used to assess potential effects of climate change on water resources of American River, CARSON RIVER, and TRUCKEE RIVER BASINS, California-Nevada, and of Gunnison River Basin, Colorado: U.S. Geological Survey Open-File Report 92-627, $72 \mathrm{p}$.
*August, M.H., and Ruddy, B.C., 1992, Hydrologic and climatic data bases used to assess the potential effects of climate change on the water resources of the American, CARSON, and TRUCKEE RIVER BASINS, California-Nevada, and of Gunnison River Basin, Colorado [abs.], in Herrmann, Raymond, ed., Managing water resources during global change: 28th Annual Conference, American Water Resources Association, Reno, Nev., November 1992, Abstracts, p. 57.

Bedinger, M.S., Harrill, J.R., Langer, W.H., Thomas, J.M., and Mulvihill, D.A., 1985, Maps showing groundwater levels, springs, and depth to ground water, BASIN AND RANGE PROVINCE, Nevada: U.S. Geological Survey Water-Resources Investigations Report 83-4119-B, 2 sheets, scale 1:500,000.

Bedinger, M.S., Harrill, J.R., and Thomas, J.M., 1985, Maps showing ground-water units and withdrawal, BASIN AND RANGE PROVINCE, Nevada: U.S. Geological Survey Water-Resources Investigations Report 83-4119-A, 2 sheets, scale 1:500,000.

Bell, J.W., and Katzer, Terry, 1987, Surficial geology, hydrology, and later Quaternary tectonics of the IXL Canyon area, Nevada-As related to the 1954 DIXIE VALLEY earthquake: Nevada Bureau of Mines and Geology Bulletin 102, 52 p.

Bell, J.W., Watters, R.J., and Glancy, P.A., 1989, Engineering geology of the RENO-LAKE TAHOE area, Nevada in Engineering geology of western United States urban centers [for 28th International Geological Congress, July 1989]: Washington, D.C., American Geophysical Union, Field Trip Guidebook T181.

Berger, D.L., 1987, Ground-water levels in water years 1984-86 and estimated ground-water pumpage in water years 1984-85, CARSON VALLEY, Douglas County, Nevada: U.S. Geological Survey Open-File Report 86-539, 16 p.

Berger, D.L., 1989, Uses of seismic refraction in waterresource investigations [abs.], in Foglesong, M.T., Bunch, R.L., and Myers, C.W., comps., Water resources for expanding State needs: Annual Conference, Nevada Water Resources Association, Carson City, Nev., March 1989, Program Information and Selected Abstracts, unpaginated. 
Berger, D.L., 1990, Ground-water levels in water year 1987 and estimated ground-water pumpage in water years 1986-87, CARSON VALLEY, Douglas County, Nevada: U.S. Geological Survey Open-File Report 89-70, 9 p.

*Berger, D.L., 1992, Ground-water recharge through active sand dunes in NORTHWESTERN NEVADA: Water Resources Bulletin, v. 28, no. 5, p. 959-965.

*Berger, D.L., 1992, Lithologic properties of carbonaterock aquifers at five test wells in the COYOTE SPRING VALLEY area, southern Nevada, as determined from geophysical logs: U.S. Geological Survey Water-Resources Investigations Report 91-4167, $27 \mathrm{p}$.

Berger, D.L., and Andraski, B.J., 1991, Simulation of ground-water recharge through eolian deposits in an arid basin, NORTHWESTERN NEVADA [abs.]: Agronomy Abstracts, American Society of Agronomy, 1991 Annual Meetings, October 1991, Denver, Colo., p. 214.

Berger, D.L., Kilroy, K.C., and Schaefer, D.H., 1988, Geophysical logs and hydrologic data for eight wells in the COYOTE SPRING VALLEY area, Clark and Lincoln Counties, Nevada: U.S. Geological Survey Open-File Report 87-679, 59 p.

Berger, D.L., Schaefer, D.H., and Frick, E.A., 1990, Principal facts for gravity stations in the ELKO, STEPTOE VALLEY, COYOTE SPRING VALLEY, and SHEEP RANGE areas, eastern and southern Nevada: U.S. Geological Survey Open-File Report 89-30, 13 p.

Beutner, M.L., and Andraski, B.J., 1989, Comparison of standard and simplified hydrometer methods for textural analysis of a desert soil near BEATTY, Nevada [abs.]: 81st Annual Meeting, American Society of Agronomy, Las Vegas, Nev., October 1989, Program of Agronomy Abstracts, v. 81, p. 184.

Bevans, H.B., and Kilroy, K.C., 1991, National WaterQuality Assessment Program-NEVADA BASIN AND RANGE: U.S. Geological Survey Open-File Report 91-154, 2 p. (Water Fact Sheet).

*Blackstun, D.E., 1991, Development of a real-time detection system for flood hazards in CLARK COUNTY, Nevada [abs.]: American Water Resources Association, Symposium on Urban Hydrology and Drainage Issues, Denver, Colo., November 1990.
Blackstun, D.E., and Cox, E.A., 1990, Automated data collection for detection of flood hazards in CLARK COUNTY, Nevada [abs.], in Balthrop, B.H., and Baker, E.G., comps., U.S. Geological Survey National Computer Technology Meeting-Program and Abstracts, May 7-11, 1990: U.S. Geological Survey Open-File Report 90-161, p. 4.

Blodgett, J.C., Oltmann, R.N., and Poeschel, K.R., 1984, Estimation of streamflow for selected sites on the CARSON and TRUCKEE RIVERS in California and Nevada, 1944-80: U.S. Geological Survey WaterResources Investigations Report 84-4058, 223 p.

Bostic, R., Hitch, D., Van Gordon, L., and Swanson, R., 1991, Water resources data, NEVADA, water year 1990: U.S. Geological Survey Water-Data Report NV-90-1, $358 \mathrm{p}$.

Brown, R.G., and Nichols, W.D., 1990, Selected meteorological data for an arid climate over bare soil near BEATTY, Nye County, Nevada, November 1977 through May 1980: U.S. Geological Survey Open-File Report 90-195, 48 p.

Brown, W.M., III, Nowlin, J.O., Smith, L.H., and Flint, M.R., 1986, River-quality assessment of the TRUC. KEE and CARSON RIVER system, California and Nevada-Hydrologic characteristics: U.S. Geological Survey Open- File Report 84-576, 201 p.

*Bunch, R.L., 1992, Bibliography of selected waterresources publications on NEVADA by the U.S. Geological Survey, 1885 through 1991: U.S. Geological Survey Open-File Report 92-42, 43 p.

Bunch, R.L., and Harrill, J.R., 1984, Compilation of selected hydrologic data from the MX missile-siting investigation, EAST-CENTRAL NEVADA and western Utah: U.S. Geological Survey Open-File Report 84-702, 123 p.

Burbey, T.J., 1987, Assessment of a salt reduction strategy for LAS VEGAS WASH, southern Nevada [abs.]: Ground Water, v. 25, no. 5, p. 611.

Burbey, T.J., 1991, Water-level and pumpage data for LAS VEGAS VALLEY, Clark County, Nevada, 1986-90: U.S. Geological Survey Open-File Report 91-496, $122 \mathrm{p}$. 
*Burbey, T.J., 1993, Calculation of horizontal granular movement in confined aquifers [abs.]: Geological Society of America, Abstracts with Programs, v. 25, no. 6, p. 258.

*Burbey, T.J., 1993, Shallow ground water in the Whitney Area, southeastern LAS VEGAS VALLEY, Clark County, Nevada-Part II, Assessment of a proposed strategy to reduce the contribution of salts to Las Vegas Wash: U.S. Geological Survey WaterResources Investigations Report 92-4051, 58 p.

Burbey, T.J., and Prudic, D.E., 1985, Simulation of regional ground-water flow in carbonate-rock aquifers of the GREAT BASIN in Nevada, Utah, and adjacent states [abs.]: Geological Society of America, Abstracts with Programs, v. 17 , no. 7, p. 534.

Burkham, D.E., 1988, Methods for delineating flood-prone areas in the GREAT BASIN of Nevada and adjacent states: U.S. Geological Survey Water-Supply Paper 2316, 20 p.

Carlsen, C.L., Lunnis, R.C., and Prudic, D.E., 1991, Changes in water levels and water quality in shallow ground water, PITTMAN-HENDERSON AREA, Clark County, Nevada, resulting from diversion of industrial cooling water from ditch to pipeline in 1985: U.S. Geological Survey Water-Resources Investigations Report 89-4093, $69 \mathrm{p}$.

Carlton, S.M., and Thomas, J.M., 1986, Documentation for a digital computer model of the basin-fill aquifer in SMITH CREEK VALLEY, Lander County, Nevada: U.S. Geological Survey contribution; available only from National Technical Information Service, U.S. Department of Commerce, Springfield, VA 22161, accession number PB-87 142899 (text) and PB-87 142907 (magnetic tape).

Carman, R.L., 1985, Estimating evapotranspiration from a phreatophyte area in SMITH CREEK VALLEY, Nevada [abs.]: 17th Conference, Agricultural and Forest Meteorology, and Seventh Conference, Biometeorology and Aerobiology, Scottsdale, Ariz., May 1985, Program, p. 48.

Carman, R.L., 1989, Data on evapotranspiration in phreatophyte areas, SMITH CREEK VALLEY and CARSON DESERT, west-central Nevada, 1983: U.S. Geological Survey contribution; available only from National Technical Information Service, U.S. Depart- ment of Commerce, Springfield, VA 22161, accession numbers PB-89 167399 (text) and PB-89 167407 (magnetic tape).

*Carman, R.L., 1993, Measurement of evapotranspiration in phreatophyte areas, SMITH CREEK VALLEY and CARSON DESERT, west-central Nevada, 1983: U.S. Geological Survey Water-Resources Investigations Report 89-4118, $18 \mathrm{p}$.

Carman, R.L., and Johnson, M.E., 1986, Analysis of recharge potential at surface disruption sites, NEVADA TEST SITE, Nevada-Study approach: Nevada Water Conference, Las Vegas, February 1986, Poster-Session Display.

Carpenter, Everett, 1915, Ground water in SOUTHEASTERN NEVADA: U.S. Geological Survey Water-Supply Paper 365, $86 \mathrm{p}$.

Carson, R.L., 1979, Water-resources data collected in the DEVILS HOLE area, Nevada, 1976-77: U.S. Geological Survey Open-File Report 79-742, 22 p.

Carson, R.L., 1980, Water-resources data collected in the DEVILS HOLE area, Nye County, Nevada, 1977-78: U.S. Geological Survey Open-File Report 80-772, $15 \mathrm{p}$.

Cartier, K.D., 1991, TEGIS GIS layers, LAKE TAHOE BASIN [California-Nevada]: 11th Annual Environmental Systems Research Institute User Conference, Palm Springs, Calif., May 1991, Poster-Session Display.

*Cartier, K.D., Peltz, L.A., and Long, K.F., 1992, Tahoe Environmental Geographic Information System, LAKE TAHOE BASIN, California and Nevada [abs.]: American Institute of Petroleum Geologists, Program with Abstracts, Lake Tahoe, September 1992, p. 11.

*Cartier, K.D., and Watson, J.C., 1992, Relational data-base management system for NEVADA water-rights information [abs.], in Balthrop, B.H., and Baker, E.G., eds., U.S. Geological Survey National Computer Technology Meeting-Program and Abstracts, Norfolk, Virginia, May 17-22, 1992: U.S. Geological Survey Open-File Report 92-62, p. 5. 
Clark, W.O., and Riddell, C.W., 1920, Exploratory drilling for water and use of ground water for irrigation in STEPTOE VALLEY, Nevada, with an Introduction by O.E. Meinzer: U.S. Geological Survey WaterSupply Paper 467, $70 \mathrm{p}$.

Cobb, E.D., Olson, A.F., Moosburner, Otto, and Pupacko, Alex, 1990, Review of selected water-management models and results of simulations for the TRUCKEECARSON RIVERS system, California and Nevada: U.S. Geological Survey Open-File Report 90-393, $40 \mathrm{p}$.

Coe, J.A., Whitney, J.W., and Glancy, P.A., 1991, Volumetric analysis of debris eroded off a hillslope near YUCCA MOUNTAIN, Nevada, during a single precipitation event [abs.]: Eos, American Geophysical Union Transactions, v. 72, no. 44/Supplement-1991 Fall Meeting Program and Abstracts, p. 204.

Cohen, Philip, 1961, An evaluation of uranium as a tool for studying the hydrochemistry of the TRUCKEE MEADOWS area, Nevada: Journal of Geophysical Research, v. 66, no. 12, p. 4199-4206.

Cohen, Philip, 1961, A preliminary evaluation of the ground-water hydrology of the valley of the HUMBOLDT RIVER, near WINNEMUCCA, NevadaA summary: 15th Nevada Water Conference, Carson City, Proceedings, p. 1-7.

Cohen, Philip, 1961, Relation of surface water to ground water in the HUMBOLDT RIVER VALLEY near WINNEMUCCA, Nevada [abs.]: Geological Society of America Special Paper 68, p. 153-154.

Cohen, Philip, 1961, Specific yield of sediments of the HUMBOLDT RIVER VALLEY, Humboldt County, Nevada: U.S. Geological Survey Professional Paper 424-C, p. 43-45.

Cohen, Philip, 1962, Estimating porosity from specific gravity, in Geological Survey Research 1962: U.S. Geological Survey Professional Paper 450-B, p. 4143.

Cohen, Philip, 1962, Hydrogeologic evidence of the extension of the East Range fault, HUMBOLDT and PERSHING COUNTIES, Nevada, in Geological Survey Research 1962: U.S. Geological Survey Professional Paper 450-B, p. 9-11.
Cohen, Philip, 1962, Preliminary results of hydrogeochemical studies in the HUMBOLDT RIVER VALLEY near WINNEMUCCA, Nevada: Nevada Department of Conservation and Natural Resources, Water Resources Bulletin 19, 27 p.

Cohen, Philip, 1962, Source of sulfate in ground water of the TRUCKEE MEADOWS area, Nevada, in Geological Survey Research 1962: U.S. Geological Survey Professional Paper 450-C, p. 131-132.

Cohen, Philip, 1962, Stratigraphy and origin of Lake Lahontan deposits of the HUMBOLDT RIVER VALLEY near WINNEMUCCA, Nevada, in Geological Survey Research 1962: U.S. Geological Survey Professional Paper 450-C, p. 63-65.

Cohen, Philip, 1963, An evaluation of the water resources of the HUMBOLDT RIVER VALLEY near WINNEMUCCA, Nevada: Nevada Department of Conservation and Natural Resources, Water Resources Bulletin 24, 103 p.

Cohen, Philip, 1963, Specific yield and particle-size relations of Quaternary alluvium, HUMBOLDT RIVER VALLEY, Nevada: U.S. Geological Survey WaterSupply Paper 1669-M, 24 p.

Cohen, Philip, 1964, A brief appraisal of the ground-water resources of the GRASS VALLEY area, Humboldt and Pershing Counties, Nevada: Nevada Department of Conservation and Natural Resources, GroundWater Resources - Reconnaissance Report 29, 40 p.

Cohen, Philip, 1964, Preliminary results of hydrologic investigations in the valley of the HUMBOLDT RIVER near WINNEMUCCA, Nevada: U.S. Geological Survey Water-Supply Paper 1754, $59 \mathrm{p}$.

Cohen, Philip, 1966, Water in the HUMBOLDT RIVER VALLEY near WINNEMUCCA, Nevada: U.S. Geological Survey Water-Supply Paper 1816, 69 p.

Cohen, Philip, and Everett, D.E., 1963, A brief appraisal of the ground-water hydrology of the DIXIE-FAIRVIEW VALLEY area: Nevada Department of Conservation and Natural Resources, Ground-Water Resources - Reconnaissance Report 23, 40 p.

Cohen, Philip, and Loeltz, O.J., 1964, Evaluation of hydrogeology and hydrogeochemistry of TRUCKEE MEADOWS area, Washoe County, Nevada: U.S. Geological Survey Water-Supply Paper 1779-S, 63 p. 
Cohen, Philip, and others, 1965, Water resources of the HUMBOLDT RIVER VALLEY near WINNEMUCCA, Nevada: U.S. Geological Survey WaterSupply Paper 1795, 143 p.

*Cole, J.C., Sawyer, D.A., Laczniak, R.J., and Trudeau, D.A., 1991, The hydrogeologic view of containment [abs.]: Sixth Symposium on Containment of Underground Nuclear Explosions, Reno, Nev., Lawrence Livermore National Laboratory, Proceedings, CONF9109114, p. 175.

Coplen, T.B., Winograd, I.J., Ludwig, K.R., Szabo, B.J., Landwehr, J.M., Kolesar, P.T., and Hoffman, R.J., 1990, Continuous 500,000-year climatic record from GREAT BASIN vein calcite-2. The $\delta^{13} \mathrm{C}$ time series [abs.]: Geological Society of America, Abstracts with Programs, v. 22, no. 7, p. 209.

Crompton, E.J., Frick, E.A., and Thiel, C.A., 1989, How NEVADA dealt its water in 1985 [abs.], in Foglesong, M.T., Bunch, R.L., and Myers, C.W., comps., Water resources for expanding State needs: Annual Conference, Nevada Water Resources Association, Carson City, Nev., March 1989, Program Information and Selected Abstracts, unpaginated.

Crompton, E.J., and Swartwood, J.R., 1990, Trends in NEVADA's public-supply water use [abs.], in Nevada decision point-Which water course to the future?: Annual Conference, Nevada Water Resources Association, Las Vegas, Nev., February 1990, Program Information and Abstracts, unpaginated.

Crosthwaite, E.G., 1963, Ground-water appraisal of ANTELOPE and MIDDLE REESE RIVER VALLEYS, Lander County, Nevada: Nevada Department of Conservation and Natural Resources, Ground-Water Resources - Reconnaissance Report 19, 33 p.

Dettinger, M.D., 1987, Ground-water quality an 1 geochemistry of LAS VEGAS VALLEY, Clark County, Nevada, 1981-83-Implementation of a monitoring network: U.S. Geological Survey Water-Resources Investigations Report 87-4007, 69 p.

Dettinger, M.D., 1987, Influence of Tertiary-age extensional tectonics on present-day regional ground-water flow and discharge in SOUTHERN NEVADA and vicinity [abs.]: Geological Society of America, Abstracts with Programs, v. 19, no. 6, p. 371-372.
Dettinger, M.D., 1988, Evaluation of ground-water resources in a structurally extended terrainGeological considerations in the EASTERN GREAT BASIN, Nevada and Utah [abs.]: Eos, American Geophysical Union Transactions, v. 69, no. 44, p. 1185.

Dettinger, M.D., 1989, Distribution of carbonate-rock aquifers in SOUTHERN NEVADA and the potential for their development-Summary of findings, 1985-88: Carson City, Nev., Program for the Study and Testing of Carbonate-Rock Aquifers in Eastern and Southern Nevada, Summary Report No. 1, 37 p.

Dettinger, M.D., 1989, Reconnaissance estimates of natural recharge to desert basins in NEVADA, U.S.A., by using chloride-balance calculations: Journal of Hydrology, v. 106, no. 1/2, p. 55-78.

Dettinger, M.D., 1990, NEVADA's carbonate-rock aquifers-Some basic information [abs.], in Nichols, Martha, Foglesong, M.T., and Topping, M.A., comps., Water-Liquid gold: Annual Conference, Nevada Water Resources Association, Carson City, Nev., February 1987, Program Information and Selected Abstracts, unpaginated.

*Dettinger, M.D., 1992, Geohydrology of areas being considered for exploratory drilling and development of the carbonate-rock aquifers in SOUTHERN NEVADAPreliminary assessment: U.S. Geological Survey Water-Resources Investigations Report 90-4077, 35 p.

*Dettinger, M.D., and Jeton, A.E., 1992, Simulated streamflow responses to climate change in the American and CARSON RIVERs of the Sierra Nevada, California and Nevada [abs.]: 9th Annual Pacific Climate Workshop (PACLIM), Asilomar, Calif., April 1992, p. 92.

Dettinger, M.D., Schaefer, D.H., and Thomas, J.M., 1990, Tertiary-age extensional patterns as a geologic framework for interpreting regional ground-water flow in the EASTERN GREAT BASIN, Nevada and Utah [abs.], in Flanigan, D.M.H., Garside, L.J., and Hansen, Mike, eds., Oil fields and geology of the Pine Valley, Eureka County area, Nevada: Reno, Nev., Nevada Petroleum Society Inc., 1990 Fieldtrip Guidebook, p. 55.

Dettinger, M.D., and Van Denburgh, A.S., 1988, U.S. Geological Survey ground-water studies in NEVADA: U.S. Geological Survey Open-File Report 88-119, 2 p. (Water Fact Sheet). 
Dudley, W.W., Jr., and Larson, J.D., 1976, Effect of irrigation pumping on desert pupfish habitats in ASH MEADOWS, Nye County, Nevada: U.S. Geological Survey Professional Paper 927, $52 \mathrm{p}$.

Duffrin, B.G., Berger, D.L., and Schaefer, D.H., 1985, Principal facts for gravity stations in the HUMBOLDT HOUSE geothermal area, Pershing County, Nevada: U.S. Geological Survey Open-File Report 85-162, $11 \mathrm{p}$.

Eakin, T.E., 1950, Preliminary report on ground water in FISH LAKE VALLEY, Nevada and California, with a statement on Reconnaissance land classification of Fish Lake Valley, Esmeralda County, Nevada by H.G. Mason: Nevada State Engineer, Water Resources Bulletin 11, $37 \mathrm{p}$.

Eakin, T.E., 1960, Ground-water appraisal of NEWARK VALLEY, White Pine County, Nevada: Nevada Department of Conservation and Natural Resources, Ground-Water Resources - Reconnaissance Report 1, $33 \mathrm{p}$.

Eakin, T.E., 1961, Ground-water appraisal of PINE VALLEY, Eureka and Elko Counties, Nevada: Nevada Department of Conservation and Natural Resources, Ground-Water Resources - Reconnaissance Report 2, $41 \mathrm{p}$.

Eakin, T.E., 1961, Ground-water appraisal of LONG VALLEY, White Pine and Elko Counties, Nevada: Nevada Department of Conservation and Natural Resources, Ground-Water Resources - Reconnaissance Report 3, 35 p.

Eakin, T.E., 1962, Ground-water appraisal of the IMLAY area, HUMBOLDT RIVER BASIN, Pershing County, Nevada: Nevada Department of Conservation and Natural Resources, Ground-Water Resources Reconnaissance Report 5, 54 p.

Eakin, T.E., 1962, Ground-water appraisal of DIAMOND VALLEY, Eureka and Elko Counties, Nevada: Nevada Department of Conservation and Natural Resources, Ground-Water Resources - Reconnaissance Report 6, 60 p.

Eakin, T.E., 1962, Ground-water appraisal of INDEPENDENCE VALLEY, western Elko County, Nevada: Nevada Department of Conservation and Natural Resources, Ground-Water Resources - Reconnaissance Report 8, 31 p.
Eakin, T.E., 1962, Ground-water appraisal of GABBS VALLEY, Mineral and Nye Counties, Nevada: Nevada Department of Conservation and Natural Resources, Ground-Water Resources - Reconnaissance Report 9, 27 p.

Eakin, T.E., 1962, Ground-water appraisal of RALSTON and STONE CABIN VALLEYS, Nye County, Nevada: Nevada Department of Conservation and Natural Resources, Ground-Water Resources - Reconnaissance Report 12, 32 p.

Eakin, T.E., 1962, Ground-water appraisal of CAVE VALLEY in Lincoln and White Pine Counties, Nevada: Nevada Department of Conservation and Natural Resources, Ground-Water Resources - Reconnaissance Report 13, 19 p.

Eakin, T.E., 1963, Ground-water appraisal of DRY LAKE and DELAMAR VALLEYS, Lincoln County, Nevada: Nevada Department of Conservation and Natural Resources, Ground-Water Resources - Reconnaissance Report 16, 26 p.

Eakin, T.E., 1963, Ground-water appraisal of GARDEN and COAL VALLEYS, Lincoln and Nye Counties, Nevada: Nevada Department of Conservation and Natural Resources, Ground-Water Resources - Reconnaissance Report 18, 29 p.

Eakin, T.E., 1963, Ground-water appraisal of PAHRANAGAT and PAHROC VALLEYS, Lincoln and Nye Counties, Nevada: Nevada Department of Conservation and Natural Resources, Ground-Water Resources - Reconnaissance Report 21, 36 p.

Eakin, T.E., 1964, Ground-water appraisal of COYOTE SPRING and KANE SPRINGS VALLEYS and MUDDY RIVER SPRINGS area, Lincoln and Clark Counties, Nevada: Nevada Department of Conservation and Natural Resources, Ground-Water Resources - Reconnaissance Report 25, 40 p.

Eakin, T.E., 1965, Ground-water drainage from alluvium to regional carbonate rock aquifers in SOUTHEASTERN NEVADA [abs.]: American Geophysical Union Transactions, v. 46 , no. 3 .

Eakin, T.E., 1965, Regional ground-water system in SOUTHEASTERN NEVADA [abs.]: Ground Water, v. 3, no. 1, p. 48. 
Eakin, T.E., 1966, A regional interbasin groundwater system in the WHITE RIVER area, southeastern Nevada: Water Resources Research, v. 2, no. 2, p. 251-271.

Eakin, T.E., Hughes, J.L., and Moore, D.O., 1967, Waterresources appraisal of STEPTOE VALLEY, White Pine and Elko Counties, Nevada: Nevada Department of Conservation and Natural Resources, Water Resources - Reconnaissance Report 42, 48 p.

Eakin, T.E., and Lamke, R.D., 1966, Hydrologic reconnaissance of the HUMBOLDT RIVER BASIN, Nevada: Nevada Department of Conservation and Natural Resources, Water Resources Bulletin 32, $107 \mathrm{p}$.

Eakin, T.E., and Maxey, G.B., 1951, Ground water in RUBY VALLEY, Elko and White Pine Counties, Nevada, in Eakin, T.E., Maxey, G.B., Robinson, T.W., Fredricks, J.C., and Loeltz, O.J., Contributions to the hydrology of eastern Nevada: Nevada State Engineer, Water Resources Bulletin 12, p. 65-93.

Eakin, T.E., Maxey, G.B., and Robinson, T.W., 1951, Ground water in GOSHUTE and ANTELOPE VALLEYS, Elko County, Nevada, in Eakin, T.E., Maxey, G.B., Robinson, T.W., Fredricks, J.C., and Loeltz, O.J., Contributions to the hydrology of eastern Nevada: Nevada State Engineer, Water Resources Bulletin 12, p. 17-34.

Eakin, T.E., Maxey, G.B., Robinson, T.W., Fredericks, J.C., and Loeltz, O.J., 1951, Contributions to the hydrology of EASTERN NEVADA: Nevada State Engineer, Water Resources Bulletin 12, $171 \mathrm{p}$.

Eakin, T.E., and Moore, D.O., 1964, Uniformity of discharge of MUDDY RIVER SPRINGS, southeastern Nevada, and relation to interbasin movement of ground water in Geological Survey Research 1964: U.S. Geological Survey Professional Paper 501-D, p. 171-176.

Eakin, T.E., Moore, D.O., and Everett, D.E., 1965, Water resources appraisal of the upper REESE RIVER VALLEY, Lander and Nye Counties, Nevada: Nevada Department of Conservation and Natural Resources, Water Resources - Reconnaissance Report 31, 47 p.
Eakin, T.E., Price, Don, and Harrill, J.R., 1976, Summary appraisals of the Nation's ground-water resourcesGREAT BASIN Region: U.S. Geological Survey Professional Paper 813-G, 37 p.

Eakin, T.E., and Robinson, T.W., 1950, Ground-water conditions in WHISKEY FLAT, Mineral County, Nevada: U.S. Geological Survey Open-File Report 50-70, $5 \mathrm{p}$.

Eakin, T.E., Schoff, S.L., and Cohen, Philip, 1963, Regional hydrology of a part of SOUTHERN NEVADA-A reconnaissance: U.S. Geological Survey Open-File Report TEI-833, $40 \mathrm{p}$.

Eakin, T.E., and Winograd, I.J., 1965, Interbasin movement of ground water in SOUTH-CENTRAL NEVADASome implications, in Abstracts for 1964: Geological Society of America Special Paper 82, p. 52.

Emme, D.H., and Prudic, D.E., 1991, Shallow ground water in the Whitney area, LAS VEGAS VALLEY, Clark County, Nevada-Part I, Description of chemical quality, 1986-87: U.S. Geological Survey WaterResources Investigations Report 89-4117, 47 p.

Everett, D.E., 1964, Ground-water appraisal of EDWARDS CREEK VALLEY, Churchill County, Nevada: Nevada Department of Conservation and Natural Resources, Ground-Water Resources - Reconnaissance Report 26, 18 p.

Everett, D.E., 1964, Map showing saline ground-water areas of NEVADA: U.S. Geological Survey OpenFile Report.

Everett, D.E., and Rush, F.E., 1964, Ground-water appraisal of SMITH CREEK and IONE VALLEYS, Lander and Nye Counties, Nevada: Nevada Department of Conservation and Natural Resources, Ground-Water Resources - Reconnaissance Report 28, 21 p.

Everett, D.E., and Rush, F.E., 1965, Water-resources appraisal of LOVELOCK VALLEY, Pershing County, Nevada: Nevada Department of Conservation and Natural Resources, Water Resources - Reconnaissance Report 32, 40 p.

Everett, D.E., and Rush, F.E., 1966, A brief appraisal of the water resources of GRASS and CARICO LAKE VALLEYS, Lander and Eureka Counties, Nevada: Nevada Department of Conservation and Natural Resources, Water Resources - Reconnaissance Report 37, 28 p. 
Everett, D.E., and Rush, F.E., 1967, A brief appraisal of the water resources of the WALKER LAKE area, Mineral, Lyon, and Churchill Counties, Nevada: Nevada Department of Conversation and Natural Resources, Water Resources - Reconnaissance Report 40, 44 p.

Fischer, J.M., 1988, Streamflow infiltration and groundwater recharge through the unsaturated zone at VICEE CANYON, Nevada: University of Nevada, Reno, unpublished M.S. thesis, 100 p.

Fischer, J.M., 1990, Geohydrology of the near-surface unsaturated zone adjacent to the disposal site for lowlevel radioactive waste near BEATTY, Nevada, in Bedinger, M.S., and Stevens, P.R., eds., Safe disposal of radionuclides in low-level radioactive waste repository sites-Low-level radioactive-waste disposal workshop, U.S. Geological Survey, July 11-16, 1987, Big Bear Lake, Calif., Proceedings: U.S. Geological Survey Circular 1036, p. 57-61.

*Fischer, J.M., 1992, Sediment properties and water movement through shallow unsaturated alluvium at an arid site for disposal of low-level radioactive waste near BEATTY, Nye County, Nevada: U.S. Geological Survey Water-Resources Investigations Report 924032, $48 \mathrm{p}$.

Fischer, J.M., and Nichols, W.D., 1986, BEATTY, Nevada, in Dinwidde, G.A., and Trask, N.J., eds., U.S. Geological Survey research in radioactive waste disposalFiscal years 1983, 1984, and 1985: U.S. Geological Survey Water-Resources Investigations Report 874009 , p. 87-88.

Flagg, V.E., Moosburner, Otto, and Katzer, Terry, 1985, Water-related scientific activities of the U.S. Geological Survey in NEVADA, fiscal years 1983-85: U.S. Geological Survey report, $64 \mathrm{p}$.

Foglesong, M.T., 1991, Water-related scientific activities of the U.S. Geological Survey in NEVADA, fiscal years 1989-90: U.S. Geological Survey Open-File Report 91-516, $82 \mathrm{p}$.

*Foglesong, M.T., 1993, Water-related scientific activities of the U.S. Geological Survey in NEVADA, fiscal years 1991-92: U.S. Geological Survey Open-File Report 93-97, 85 p.
Frick, E.A., 1985, Quantitative analysis of ground water flow in valley-fill deposits in STEPTOE VALLEY, Nevada: University of Nevada, Reno, unpublished M.S. thesis, 192 p.

Frick, E.A., 1987, Geographical information system for interpreting and displaying geochemistry of soil, shallow aquifer material, and ground water in the CARSON RIVER BASIN, Nevada and CaliforniaProject objectives and plans [abs.], in Abstracts of papers presented at the Geographical Information Systems Symposium, Reston, Va., June 1987: U.S. Geological Survey Open-File Report 87-314, p. 32-33.

Frick, E.A., 1990, Refined concepts of the ground-water flow system in STEPTOE VALLEY, east-central Nevada [abs.]: Geological Society of America, Abstracts with Programs, v. 22, no. 3, p. 23.

Frick, E.A., and Carman, R.L., 1990, NEVADA water supply and demand, in Carr, J.E., Chase, E.B., Paulson, R.W., and Moody, D.W., comps., National water summary 1987-Hydrologic events and water supply and use: U.S. Geological Survey Water-Supply Paper 2350, p. 353-360.

Frisbie, H.R., La Camera, R.J., Riek, M.M., and Wood, D.B., 1982, Water resources data for NEVADA, water year 1981: U.S. Geological Survey Water-Data Report NV-81-1, 404 p.

Frisbie, H.R., La Camera, R.J., Riek, M.M., and Wood, D.B., 1983, Water resources data for NEVADA, water year 1982: U.S. Geological Survey Water-Data Report NV-82-1, 366 p.

Frisbie, H.R., La Camera, R.J., Riek, M.M., and Wood, D.B., 1985, Water resources data for NEVADA, water year 1983: U.S. Geological Survey Water-Data Report NV-83-1, 328 p.

Frisbie, H.R., La Camera, R.J., Riek, M.M., and Wood, D.B., 1985, Water resources data, NEVADA, water year 1984: U.S. Geological Survey Water-Data Report NV-84-1, 247 p.

Frisbie, H.R., La Camera, R.J., Riek, M.M., and Wood, D.B., 1985 [1988], Water resources data, NEVADA, water year 1985: U.S. Geological Survey Water-Data Report NV-85-1, 255 p. 
Gale, H.S., 1914, Notes on the Quaternary lakes of the GREAT BASIN, with special reference to the deposition of potash and other salines: U.S. Geological Survey Bulletin 540, p. 399-406.

Garcia, K.T., 1988, Effect of erosion-control structures on sediment and nutrient transport, EDGEWOOD CREEK drainage, LAKE TAHOE BASIN, Nevada, 1981-83: U.S. Geological Survey Water-Resources Investigations Report 87-4072, 65 p.

Garcia, K.T., 1989, Ground-water quality in DOUGLAS COUNTY, western Nevada: U.S. Geological Survey Water-Resources Investigations Report 87-4269, $107 \mathrm{p}$.

Garcia, K.T., and Carman, R.L., 1986, Water-quality characteristics and nutrient and suspended-sediment loads, CARSON RIVER and TRUCKEE CANAL, western Nevada, water year 1980: U.S. Geological Survey Water-Resources Investigations Report 85-4147, $107 \mathrm{p}$.

*Garcia, K.T., Gortsema, G.C., Pennington, R.N., and Preissler, A.M., 1992, Water resources data, NEVADA, water year 1991: U.S. Geological Survey Water-Data Report NV-91-1, 481 p.

Garcia, K.T., and Jacoboni, J.M., 1991, Data on groundwater quality in the WINNEMUCCA District of the U.S. Bureau of Land Management, northwestern Nevada, 1934-87: U.S. Geological Survey Open-File Report 89-424, 150 p.

Glancy, P.A., 1968, Water-resources appraisal of MESQUITE-IVANPAH VALLEY area, Nevada and California: Nevada Division of Water Resources, Reconnaissance Report 46, 57 p.

Glancy, P.A., 1968, Water-resources appraisal of BUTTE VALLEY, Elko and White Pine Counties, Nevada: Nevada Division of Water Resources, Reconnaissance Report 49, $50 \mathrm{p}$.

Glancy, P.A., 1969, A mudflow in the SECOND CREEK drainage, LAKE TAHOE BASIN, Nevada, and its relation to sedimentation and urbanization in Geological Survey Research 1969: U.S. Geological Survey Professional Paper 650-C, p. 195-200.
Glancy, P.A., 1971, A reconnaissance of streamflow and fluvial sediment transport, INCLINE VILLAGE area, LAKE TAHOE, Nevada, first progress report, 1970: Nevada Division of Water Resources, Information Report 8, 28 p.

Glancy, P.A., 1971, Water-resources appraisal of ANTELOPE VALLEY and EAST WALKER area, Nevada and California: Nevada Division of Water Resources, Reconnaissance Report 53, 69 p.

Glancy, P.A., 1973, A reconnaissance of streamflow and fluvial sediment transport, INCLINE VILLAGE area, LAKE TAHOE, Nevada, second progress report, 1971: Nevada Division of Water Resources, Information Report 19, 37 p.

Glancy, P.A., 1976, A reconnaissance of streamflow and fluvial sediment transport, INCLINE VILLAGE area, LAKE TAHOE, Nevada, third progress report, 1972 and 1973: Nevada Division of Water Resources, Information Report 23, 42 p.

Glancy, P.A., 1976, Miscellaneous hydrologic data collected during a reconnaissance of streamflow and fluvial sediment transport, INCLINE VILLAGE area, LAKE TAHOE BASIN, Nevada, 1970-73: U.S. Geological Survey Open-File Report 76-483, 14 p.

Glancy, P.A., 1977, A reconnaissance of sediment transport, streamflow, and chemical quality, GLENBROOK CREEK, LAKE TAHOE BASIN, Nevada: Nevada Highway Department Hydrologic Report 2, $54 \mathrm{p}$.

Glancy, P.A., 1982, Geohydrology of the basalt and unconsolidated sedimentary aquifers in the FALLON area, Churchill County, Nevada [abs.]: Geological Society of America, Abstracts with Programs, v. 14, no. 6, p. 312 .

Glancy, P.A., 1984, Aquifers near FALLON, Nevada, in Lintz, Joseph, Jr., ed., Western geological excursions [in conjunction with 1984 annual meetings of Geological Society of America and affiliated societies]: University of Nevada, Reno, Mackay School of Mines, v. 3, p. 115-117.

Glancy, P.A., 1984, Flash flooding-A critical hydrologic process that relates man and geomorphology in WESTERN NEVADA in Lintz, Joseph, Jr., ed., Western geological excursions [in conjunction with 
1984 annual meetings of Geological Society of America and affiliated societies]: University of Nevada, Reno, Mackay School of Mines, v. 3, p. 113-114.

Glancy, P.A., 1985, The OPHIR CREEK debris flood of May 30,1983-A real test of geohydrologic hazard mapping [abs.]: Specialty Conference on Delineation of Landslide, Flash Flood, and Debris Flow Hazards in Utah, Logan, Utah, June 1984, Proceedings, p. 195196.

Glancy, P.A., 1986, Geohydrology of the basalt and unconsolidated sedimentary aquifers in the FALLON area, Churchill County, Nevada: U.S. Geological Survey Water-Supply Paper 2263, 62 p.

Glancy, P.A., 1988, Streamflow, sediment transport, and nutrient transport at INCLINE VILLAGE, LAKE TAHOE, Nevada, 1970-73: U.S. Geological Survey Water-Supply Paper 2313, 53 p.

Glancy, P.A., and Harmsen, Lynn, 1975, A hydrologic assessment of the September 14, 1974, flood in ELDORADO CANYON, Nevada: U.S. Geological Survey Professional Paper 930, 28 p.

Glancy, P.A., and Katzer, T.L., 1975, Probable effects of the LEVIATHAN CREEK basin landslide, Douglas County, Nevada: U.S. Geological Survey Open-File Report 75-75, 3 p.

Glancy, P.A., and Katzer, T.L., 1976, Water-resources appraisal of the CARSON RIVER BASIN, western Nevada: Nevada Division of Water Resources, Reconnaissance Report 59, 126 p.

Glancy, P.A., and Katzer, T.L., 1977, Flood and related debris-flow hazards, WASHOE CITY quadrangle [Nevada]: Nevada Bureau of Mines and Geology Urban Maps Series, Washoe Lake Folio, Map 5A1, scale $1: 24,000$.

Glancy, P.A, and Rush, F.E., 1968, Water-resources appraisal of SMOKE CREEK-SAN EMIDIO DESERT area, Nevada and California: Nevada Department of Conservation and Natural Resources, Water Resources - Reconnaissance Report 44, 57 p.

Glancy, P.A., and Van Denburgh, A.S., 1969, Waterresources appraisal of the lower VIRGIN RIVER VALLEY area, Nevada, Arizona, and Utah: Nevada Division of Water Resources, Reconnaissance Report $51,87 \mathrm{p}$.
Glancy, P.A., Van Denburgh, A.S., and Born, S.M., 1972, Runoff, erosion, and solutes in the lower TRUCKEE RIVER, Nevada, during 1969: Water Resources Bulletin, v. 8, no. 6, p. 1157-1172.

Glancy, P.A., and Whitney, J.W., 1986, LAS VEGAS WASH-Dynamic evolution of a southern Nevada drainage channel [abs.]: Geological Society of America, Abstracts with Programs, v. 18, no. 6, p. 615.

Glancy, P.A., and Whitney, J.W., 1989, Recent hydrogeologic changes in lower LAS VEGAS WASH, Clark County, Nevada [abs.]: Eos, American Geophysical Union Transactions, v. 70, no. 43.

*Gortsema, G.C., 1993, Selected data on water quantity and quality at four sites on streams draining public lands, COLORADO RIVER BASIN, southeastern Nevada, October 1988 - September 1991: U.S. Geological Survey Open-File Report 93-439, 31 p.

Haines, C.F., Van Sickle, D.M., and Ryals, W.G., 1949, Range water resources of a part of the ELKO Grazing District, Elko County, Nevada: U.S. Geological Survey Open-File Report 49-76, 84 p.

*Hale, G.S., and Trudeau, D.A., 1993, Groundwater levels from well and test-hole data, Yucca Flat, NEVADA TEST SITE, Nye County, Nevada, 1959-91 [abs.]: 7th Symposium on Containment of Underground Nuclear Explosions, Kent, Wash., September 1993, Abstracts (CONF-9309103-ABS), p. 39.

*Hallock, R.J., and Hallock, L.L., eds., 1993, Detailed study of irrigation drainage in and near wildlife management areas, west-central Nevada, 1987-90—Part B, Effect on biota in STILLWATER and FERNLEY WILD. LIFE MANAGEMENT AREAS and other nearby wetlands: U.S. Geological Survey Water-Resources Investigations Report 92-4042-B, 84 p.

*Hamilton, P.A., Welch, A.H., Christenson, S.C., and Alley, W.M., 1993, Uses and limitations of existing ground-water quality data, in Alley, W.M., ed., Regional ground-water quality: New York, Van Nostrand Reinhold, chap. 25, p. 613-622.

Hammermeister, D.P., and Walmsley, S.J., 1985, Hydrologic data for LEVIATHAN MINE and vicinity, Alpine County, California, 1981-83: U.S. Geological Survey Open-File Report 85-160, 161 p. 
Handman, E.H., 1988, Ground-water resources of HONEY LAKE VALLEY, Nevada and California: U.S. Geological Survey Open-File Report 88-306, 2 p. (Water Fact Sheet).

Handman, E.H., 1990, Principal results of a ground-water study of HONEY LAKE VALLEY, California and Nevada: U.S. Geological Survey Open-File Report 90-155, 2 p. (Water Fact Sheet).

*Handman, E.H., 1992, Hydrologic aspects of interbasin transport of ground water from HONEY LAKE VALLEY, Washoe County, Nevada [abs.], in Herrmann, Raymond, ed., Managing water resources during global change: 28th Annual Conference, American Water Resources Association, Reno, Nev., November 1992, Abstracts, p. 17.

Handman, E.H., Londquist, C.J., and Maurer, D.K., 1990, Ground-water resources of HONEY LAKE VALLEY, Lassen County, California, and Washoe County, Nevada: U.S. Geological Survey Water-Resources Investigations Report 90-4050, $112 \mathrm{p}$.

Hanes, W.T., 1976, Water-resources data collected in the DEVILS HOLE area, Nevada, 1975-76: U.S. Geological Survey Open-File Report 76-797, 15 p.

Harbeck, G.E., Jr., Kohler, M.A., and Koberg, G.E., 1958, Water-loss investigations-LAKE MEAD studies: U.S. Geological Survey Professional Paper 298, 100 p.

Harrill, J.R., 1968, Hydrologic response to irrigation pumping in DIAMOND VALLEY, Eureka and Elko Counties, Nevada, 1950-65, with a section on surface water by R.D. Lamke: Nevada Department of Conservation and Natural Resources, Water Resources Bulletin 35, $85 \mathrm{p}$.

Harrill, J.R., 1969, Hydrologic response to irrigation pumping in HUALAPAI FLAT, Washoe, Pershing, and Humboldt Counties, Nevada, 1960-67: Nevada Division of Water Resources, Bulletin 37, 75 p.

Harrill, J.R., 1970, Determining transmissivity from the water-level recovery of a step-drawdown test: U.S. Geological Survey Professional Paper 700-C, p. 212213.

Harrill, J.R., 1970, Water-resources appraisal of the GRANITE SPRINGS VALLEY area, Pershing, Churchill, and Lyon Counties, Nevada: Nevada Division of Water Resources, Reconnaissance Report 55, $36 \mathrm{p}$.
Harrill, J.R., 1971, Water-resources appraisal of the PILOT CREEK VALLEY area, Elko and White Pine Counties, Nevada: Nevada Division of Water Resources, Reconnaissance Report 56, 46 p.

Harrill, J.R., 1972, Water-level changes associated with ground-water development in LAS VEGAS VALLEY, Nevada, 1971-72, first progress report: U.S. Geological Survey Open-File Report, 20 p.

Harrill, J.R., 1973, Evaluation of the water resources of LEMMON VALLEY, Washoe County, Nevada, with emphasis on effects of ground-water development to 1971: Nevada Division of Water Resources, Bulletin $42,130 \mathrm{p}$.

Harrill, J.R., 1973, Water-level changes associated with ground-water development in LAS VEGAS VALLEY, Nevada, 1972-73, second progress report: U.S. Geological Survey Open-File Report, 39 p.

Harrill, J.R., 1974, Water-level changes associated with ground-water development in LAS VEGAS VALLEY, Nevada, 1973-74, third progress report: U.S. Geological Survey Open-File Report, 36 p.

Harrill, J.R., 1976, Pumping and ground-water storage depletion in LAS VEGAS VALLEY, Nevada, 195574: Nevada Division of Water Resources, Bulletin 44, $70 \mathrm{p}$.

Harrill, J.R., 1976, Water-level changes associated with ground-water development in LAS VEGAS VALLEY, Nevada, 1971-75, fourth progress reportSummary of data: Nevada Division of Water Resources, Information Report 22, 46 p.

Harrill, J.R., 1977, Hydrologic map, SOUTH LAKE TAHOE quadrangle: Nevada Bureau of Mines and Geology Urban Map Series, Map 2Af, scale 1:24,000.

Harrill, J.R., 1977, Water-level changes associated with ground-water development in LAS VEGAS VALLEY, Nevada, March 1975 to March 1976: Nevada Division of Water Resources, Information Report 26, $31 \mathrm{p}$.

Harrill, J.R., 1984, GREAT BASIN aquifer systems, Nevada-Utah-An overview, in Repogle, J.A., and Renard, K.G., eds., Water today and tomorrow: Specialty Conference, Irrigation and Drainage Division, American Society of Civil Engineers, July 1984, Proceedings, p. 590-597. 
Harrill, J.R., 1986, GREAT BASIN regional aquifer-system study, in Sun, R.J., ed., Regional aquifer-system analysis program of the U.S. Geological SurveySummary of projects, 1978-84: U.S. Geological Survey Circular 1002, p. 146-151.

Harrill, J.R., 1986, Ground-water storage depletion in PAHRUMP VALLEY, Nevada-California, 196275: U.S. Geological Survey Water-Supply Paper $2279,53 \mathrm{p}$.

Harrill, J.R., 1986, Hydrology, SOUTH LAKE TAHOE quadrangle, Nevada and California: Nevada Bureau of Mines and Geology Open-File Report 86-4 [supplement to Urban Map 2Af], 4 p.

Harrill, J.R., Gates, J.S., and Thomas, J.M., 1988, Major ground-water flow systems in the GREAT BASIN region of Nevada, Utah, and adjacent states: U.S. Geological Survey Hydrologic Investigations Atlas HA-694-C, 2 sheets.

Harrill, J.R., Gates, J.S., Thomas, J.M., and Mifflin, M.D., 1988, Ground-water flow systems in the GREAT BASIN, in Hydrogeology: Geological Society of America, The Geology of North America, v. 0-2, plate 3, scale 1:1,000,000.

Harrill, J.R., and Katzer, Terry, 1980, General ground water, LAS VEGAS SE quadrangle: Nevada Bureau of Mines and Geology Urban Map Series, Map 3Af, scale 1:24,000.

Harrill, J.R., and Moore, D.O., 1970, Effects of groundwater development on the water regimen of PARADISE VALLEY, Humboldt County, Nevada, 194868 , and hydrologic reconnaissance of the tributary areas: Nevada Division of Water Resources, Bulletin $39,123 \mathrm{p}$.

Harrill, J.R., and Nowlin, J.O., 1976, Ground-water data near the northwest shore of TOPAZ LAKE, Douglas County, Nevada: U.S. Geological Survey Open-File Report 76-90, 12 p.

Harrill, J.R., Welch, A.H., and Preissler, A.M., 1984, Hydrogeologic controls on ground-water flow in STAGECOACH VALLEY, Nevada, in Lintz, Joseph, Jr., ed., Western geological excursions [in conjunction with 1984 annual meetings of Geological Society of America and affiliated societies]: University of Nevada, Reno, Mackay School of Mines, v. 3, p. $117-120$.
*Harrill, J.R., Welch, A.H., and Preissler, A.M., 1992, Hydrogeochemical evidence for subsurface inflow to STAGECOACH VALLEY, Lyon County, Nevada, in Subitzky, Seymour, ed., Selected papers in the hydrologic sciences, 1988-92: U.S. Geological Survey Water-Supply Paper 2340, p. 179-193.

Harrill, J.R., Welch, A.H., Prudic, D.E., Thomas, J.M., Carman, R.L., Plume, R.W., Gates, J.S., and Mason, J.L., 1983, Aquifer systems in the GREAT BASIN region of Nevada, Utah, and adjacent states-A study plan: U.S. Geological Survey Open-File Report 82$445,49 \mathrm{p}$.

Harrill, J.R., and Worts, G.F., Jr., 1968, Estimated water use in NEVADA, 1950-65: Nevada Division of Water Resources, Information Report 7, 37 p.

Harris, E.E., 1970, Reconnaissance bathymetry of PYRAMID LAKE, Washoe County, Nevada: U.S. Geological Survey Hydrologic Investigations Atlas 379, 1 sheet.

*Hawkins, W.L., Trudeau, D.A., and Drellack, S.L., 1993, Hydrogeologic investigations at the NEVADA TEST SITE, in Eckstein, Yoram, and Zaporozec, Alexander, eds., Industrial and agricultural impacts on the hydrologic environment: Second USA/CIS Joint Conference on Environmental Hydrology and Hydrogeology, Water Environment Federation, American Institute of Hydrology, Proceedings, 18 p.

Hawkins, W.L., Trudeau, D.A., and Mihevc, T.M., 1990, Hydrologic testing in exploratory drill-hole Ue4t, Yucca Flat, the NEVADA TEST SITE, in Olsen, C.W., and Carter, J.A., eds., Proceedings of the Fifth Symposium on Containment of the Underground Nuclear Explosions [September 1989]_-Volume 2: Santa Barbara, Calif., Mission Research Corp., p. 141159.

*Hess, D.L., Mello, K.A., Sexton, R.J., and Young, R.L., 1993, Water resources data, NEVADA, water year 1992: U.S. Geological Survey Water-Data Report NV-92-1, $511 \mathrm{p}$.

*Hidaka, F.T., 1977, Activities of the Water Resources Division in NEVADA: U.S. Geological Survey report, $11 \mathrm{p}$. 
*Hines, L.B., 1992, Quantification of natural ground-water evaporation in SMITH CREEK VALLEY, Lander County, Nevada, in Subitzky, Seymour, ed., Selected papers in the hydrologic sciences, 1988-92: U.S. Geological Survey Water-Supply Paper 2340, p. 9-20.

Hoffman, R.J., 1982, Intragravel pipe for measuring the quality of water in salmonid spawning gravel [abs.]: Joint Technical Conference, American Fisheries Society and the Wildlife Society, Reno, Nev., January 22.

Hoffman, R.J., 1986, A horizontal intragravel pipe for sampling water quality in salmonid spawning gravel: North American Journal of Fisheries Management, v. 6, p. $445-448$.

Hoffman, R.J., 1988, Chronology of diving activities and underground surveys in DEVILS HOLE and DEVILS HOLE CAVE, Nye County, Nevada, 1950-86: U.S. Geological Survey Open-File Report 88-93, 12 p.

Hoffman, R.J., 1989, Preliminary report of potentially toxic trace elements and pesticides in water, sediment, and biota in and near the STILLWATER WILDLIFE MANAGEMENT AREA, Churchill County, Nevada, 1986-87, Department of the Interior Irrigation Drainage Program, in Howard, A.Q., ed., Selenium and agricultural drainage-Implications for San Francisco Bay and the California environment: Fourth Selenium Symposium, Berkeley, Calif., March 1987, Proceedings, p. 163-167.

Hoffman, R.J., 1990, Phosphorus in the TRUCKEE RIVER between Vista and Patrick, Storey and Washoe Counties, Nevada, August 1984: U.S. Geological Survey Water-Resources Investigations Report 89-4175, $33 \mathrm{p}$.

Hoffman, R.J., Hallock, R.J., Rowe, T.G., Lico, M.S., Burge, H.L., and Thompson, S.P., 1990, Reconnaissance investigation of water quality, bottom sediment, and biota associated with irrigation drainage in and near STILLWATER WILDLIFE MANAGEMENT AREA, Churchill County, Nevada, 1986-87: U.S. Geological Survey Water-Resources Investigations Report 89-4105, 150 p.

Hoffman, R.J., and Scoppettone, G.G., 1988, Effect of water quality on survival of Lahontan cutthroat trout eggs in the TRUCKEE RIVER, west-central Nevada and eastern California: U.S. Geological Survey Water-Supply Paper 2319, 21 p.
Hood, J.W., and Rush, F.E., 1965, Water-resources appraisal of the SNAKE VALLEY area, Utah and Nevada: Nevada Department of Conservation and Natural Resources, Water Resources - Reconnaissance Report 34, 43 p.

*Hoover, D.L., and Trudeau, D.A., 1987, High water levels in drill holes, YUCCA FLAT, Nevada Test Site: Fourth Symposium on the Containment of Underground Nuclear Explosions, Colorado Springs, Colo., Proceedings, CONF-870961, v. 2, p. 363-372.

Hose, R.K., and Taylor, B.E., 1974, Geothermal systems of NORTHERN NEVADA: U.S. Geological Survey Open-File Report 74-271, $31 \mathrm{p}$.

Hughes, J.L., 1966, Some aspects of the hydrogeology of the SPRING MOUNTAINS and PAHRUMP VALLEY, Nevada, and environs, as determined by spring evaluation: University of Nevada, Reno, unpublished M.S. thesis, $116 \mathrm{p}$.

Hughes, J.L., Lico, M.S., and Welch, A.H., 1989, Hydrogeologic controls on the distribution of radon-222 in ground water of WEST-CENTRAL NEVADA [abs.], in Pei. son, G.L., and Smith, M.M., comps., U.S. Geological Survey Second National Symposium on Water Quality -Abstracts of the Technical Sessions, Orlando, Florida, November 12-17, 1989: U.S. Geological Survey Open-File Report 89-409, p. 40-41.

Hunt, C.B., and Robinson, T.W., 1960, Possible interbasin circulation of ground water in the southern part of the GREAT BASIN: U.S. Geological Survey Professional Paper 400-B, p. 273-274.

Huxel, C.J., Jr., and Harris, E.E., 1969, Water resources and development in MASON VALLEY, Lyon and Mineral Counties, Nevada, 1948-65: Nevada Division of Water Resources, Bulletin 38, 77 p.

Huxel, C.J., Jr., Parkes, J.E., and Everett, D.E., 1966, Effects of irrigation development on the water supply of QUINN RIVER VALLEY area, Nevada and Oregon, 1950-64: Nevada Department of Conservation and Natural Resources, Water Resources Bulletin 34, $80 \mathrm{p}$.

Jeton, A.E., 1991, Simulating watershed responses to climate in the CARSON, American, and TRUCKEE RIVER BASINS, California and Nevada: Abstracts on Climate Variability of the Eastern North Pacific 
and Western North America, 8th Annual PACLIM Workshop, Pacific Grove, Calif., March 1991, p. 1314.

*Jeton, A.E., 1992, Calibration of two SIERRA NEVADA watersheds and application of a geographic information system to model parameterization [abs.]: 9th Annual Pacific Climate Workshop (PACLIM), Asilomar, Calif., April 1992, p. 33.

*Jeton, A.E., and Smith, J.L., 1993, Development of watershed models for two SIERRA NEVADA basins using a geographic information system: American Water Resources Association, Geographic Information Systems and Water Resources, Mobile, Ala., March 1993, Proceedings, p. 251-258.

*Jeton, A.E., and Smith, J.L., 1993, Watershed modelingSpatial partitioning using GIS, in Burton, J.S., comp., Proceedings $r$ ' the Federal Interagency Workshop on Hydrologic Modeling Demands for the 90's: U.S. Geological Survey Water-Resources Investigations Report 93-4018, p. 5-81-5-88.

*Johnson, M.J., 1992, Quantifying evapotranspiration in desert environments [abs.]: American Institute of Petroleum Geologists, Program with Abstracts, Lake Tahoe, September 1992, p. 13.

*Johnson, M.J., 1993, Micrometeorological measurements at ASH MEADOWS and CORN CREEK SPRINGS, Nye and Clark Counties, Nevada, 198687: U.S. Geological Survey Open-File Report 92-650, $41 \mathrm{p}$. and 3 diskettes.

Katzer, T.L., 1971, Reconnaissance bathymetric map and general hydrology of LAHONTAN RESERVOIR, Nevada: Nevada Division of Water Resources, Information Report 9, 1 sheet.

Katzer, T.L., and Glancy, P.A., 1978, Flood and debris hazards along principal streams, SOUTH LAKE TAHOE quadrangle [Nevada and California]: Nevada Bureau of Mines and Geology Urban Map Series, South Lake Tahoe Folio, Map 2A1, scale 1:24,000.

Katzer, T.L., Glancy, P.A., and Harmsen, Lynn, 1976, A brief appraisal of the July 3-4, 1975, flash flood in LAS VEGAS VALLEY, Nevada: U.S. Geological Survey Open-File Report 76-100, 40 p.
Katzer, T.L., and Harmsen, Lynn, 1973, Bathymetric reconnaissance of WEBER RESERVOIR, Mineral County, Nevada: Nevada Division of Water Resources, Information Report 15, 1 map.

Katzer, T.L., and Harmsen, Lynn, 1973, Bathymetric reconnaissance of WILDHORSE RESERVOIR, Elko County, Nevada: Nevada Division of Water Resources, Information Report 16, 1 map.

Katzer, Terry, 1977, Water-level changes associated with ground-water development in LAS VEGAS VALLEY, Nevada, March 1976 to March 1977: Nevada Division of Water Resources, Information Report 27, $34 \mathrm{p}$.

Katzer, Terry, 1980, General ground-water map, CARSON CITY quadrangle: Nevada Bureau of Mines and Geology Urban Maps Series, Carson City Folio, Map 1Af, scale 1:24,000.

Katzer, Terry, 1982, Flood and related debris flow hazards, LAS VEGAS SE quadrangle: Nevada Bureau of Mines and Geology Urban Map Series, Las Vegas SE Folio, Map 3Al, scale 1:24,000.

Katzer, Terry, 1983, Sediment transport model for the East Fork of the CARSON RIVER, CARSON VALLEY, Nevada: Lexington, Ky., Tenth International Symposium on Urban Hydrology, Hydraulics, and Sediment Control, July 1983, Proceedings, p. 421-435.

Katzer, Terry, 1986, Ground water hydrology, CARSON CITY quadrangle, Nevada: Nevada Bureau of Mines and Geology Open-File Report 86-7 [supplement to Urban Map 1Af], 4 p.

Katzer, Terry, 1986, Flood and related debris flow hazards, LAS VEGAS SE quadrangle, Nevada: Nevada Bureau of Mines and Geology Open-File Report 86-5 [supplement to Urban Map 3A1], $4 \mathrm{p}$.

Katzer, Terry, 1986, Flood and related debris flow hazards, LAS VEGAS SW quadrangle [Nevada]: Nevada Bureau of Mines and Geology Urban Maps Series, Las Vegas SW Folio, Map 3Bl, scale 1:24,000.

Katzer, Terry, and Bennett, J.P., 1980, Sediment transport model for the east fork of the CARSON RIVER, CARSON VALLEY, Nevada: U.S. Geological Survey Open-File Report 80-160, 35 p. 
Katzer, Terry, Durbin, T.J., and Maurer, D.K., 1984, Waterresources appraisal of the GALENA CREEK basin, Washoe County, Nevada: U.S. Geological Survey Open-File Report 84-433, 59 p.

Katzer, Terry, and Glancy, P.A., 1986, Flood and related debris-flow hazards, SOUTH LAKE TAHOE quadrangle, Nevada and California: Nevada Bureau of Mines and Geology Open-File Report 86-8 [supplement to Urban Map 1A1], 12 p.

Katzer, Terry, Harrill, J.R., Berggren, Gregg, and Plume, R.W., 1985, Ground-water map, LAS VEGAS SW quadrangle: Nevada Bureau of Mines and Geology Urban Maps Series, Las Vegas SW Folio, Map 3Bf, scale $1: 24,000$.

Katzer, Terry, Moosburner, Otto, and Nichols, W.D., 1984, Investigations and research in NEVADA by the Water Resources Division, U.S. Geological Survey, 1982-83: U.S. Geological Survey Open-File Report 83-768, $40 \mathrm{p}$.

Katzer, Terry, and Schroer, C.V., 1981, Flood and related debris-flow hazards, CARSON CITY quadrangle: Nevada Bureau of Mines and Geology Urban Map Series, Carson City Folio, Map 1A1, scale 1:24,000.

Katzer, Terry, and Schroer, C.V., 1986, Flood and related debris-flow hazards, CARSON CITY quadrangle, Nevada: Nevada Bureau of Mines and Geology OpenFile Report 86-8 [supplement to Urban Map 1A1], $12 \mathrm{p}$.

Katzer, Terry, and Squires, R.R., 1984, Flood and related debris-flow hazards, LAS VEGAS SW quadrangle: Nevada Bureau of Mines and Geology Urban Maps Series, Las Vegas SW Folio, Map 3BI, scale 1:24,000.

Kilroy, K.C., 1989, Water-related scientific activities of the U.S. Geological Survey in NEVADA, fiscal years 1985-89: U.S. Geological Survey Open-File Report 89-264, $99 \mathrm{p}$.

Kilroy, K.C., 1991, Ground-water conditions in AMARGOSA DESERT, Nevada-California, 1952-87: U.S. Geological Survey Water-Resources Investigations Report 89-4101, 93 p.

La Camera, R.J., and Browning, S.B., 1988, Data on surface-water quality and quantity, lower EDGEWOOD CREEK BASIN, Douglas County, Nevada, 198485: U.S. Geological Survey Open-File Report 87-565, $18 \mathrm{p}$.
La Camera, R.J., Hoffman, R.J., Nowlin, J.O., Smith, L.H., and Lima, S.M., 1985, Data on surface-water quality and quantity, TRUCKEE RIVER system, Nevada and California, 1979-81: U.S. Geological Survey Open-File Report 84-238, 189 p.

Lamke, R.D., 1963, Flood investigations in NEVADA, August 1, 1962, to August 1, 1963, second progress report: U.S. Geological Survey Open-File Report.

Lamke, R.D., 1964, Flood investigations in NEVADA, August 1, 1963, to August 1, 1964, third progress report: U.S. Geological Survey Open-File Report.

Lamke, R.D., 1965, Flood investigations in NEVADA, August 1, 1964, to August 1, 1965, fourth progress report: U.S. Geological Survey Open-File Report.

Lamke, R.D., 1966, Flood investigations in NEVADA, August 1, 1965, to August 1, 1966, fifth progress report: U.S. Geological Survey Open-File Report.

Lamke, R.D., 1967, Flood investigations in NEVADA, August 1, 1966, to May 1, 1967, sixth progress report: U.S. Geological Survey Open-File Report.

Lamke, R.D., 1969, Flood investigations in NEVADA, May 1968-May 1969, progress report 7: U.S. Geological Survey Open-File Report.

Lamke, R.D., 1970, Flood investigations in NEVADA, May 1969-May 1970, progress report 8: U.S. Geological Survey Open-File Report.

Lamke, R.D., 1971, Flood investigations in NEVADA, May 1970-May 1971, progress report 9: U.S. Geological Survey Open-File Report.

Lamke, R.D., and Moore, D.O., 1965, Interim inventory of surface water resources of NEVADA: Nevada Department of Conservation and Natural Resources, Water Resources Bulletin 30, 50 p.

Larson, J.D., 1974, Water-resources data collected in the DEVILS HOLE area, Nevada, 1972-73: U.S. Geological Survey Water-Resources Investigations Report 61-73, 20 p.

Larson, J.D., 1974, Water-resources data collected in the DEVILS HOLE area, Nevada, 1973-74: U.S. Geological Survey Open-File Report 74-330, 12 p. 
Larson, J.D., 1975, Water-resources data collected in the DEVILS HOLE area, Nevada, 1974-75: U.S. Geological Survey Open-File Report, 12 p.

Larson, J.D., and Weir, J.E., 1969, Inventory of springs in the MOREY PEAK area of central Nevada: U.S. Geological Survey Report USGS-474-19, 22 p.; available only from National Technical Information Service, U.S. Department of Commerce, Springfield, VA 22161.

Lawrence, S.J., and Whitney, Rita, 1990, Shallow groundwater quality in the vicinity of a small urban area in WEST-CENTRAL NEVADA [abs.], in Nevada decision point-Which water course to the future? Annual Conference, Nevada Water Resources Association, Las Vegas, Nev., February 1990, Program Information and Abstracts, unpaginated.

*Leake, S.A., and Prudic, D.E., 1991, Documentation of a computer program to simulate aquifer-system compaction using the modular finite-difference ground-water flow model: U.S. Geological Survey Techniques of Water-Resources Investigations, Book 6, Chap. A2, $28 \mathrm{p}$.

Lico, M.S., 1989, Geochemistry of ground water at and near FERNLEY WILDLIFE MANAGEMENT AREA, Lyon County, Nevada [abs.], in Pederson, G.L., and Smith, M.M., comps., U.S. Geological Survey Second National Symposium on Water Quality-Abstracts of the Technical Sessions, Orlando, Florida, November 12-17, 1989: U.S. Geological Survey Open-File Report 89-409, p. 52.

*Lico, M.S., 1992, Data for radon-222 and other radionuclides in ground water, NEVADA, 1986-89: U.S. Geological Survey Open-File Report 91-488, 17 p.

*Lico, M.S., 1992, Detailed study of irrigation drainage in and near wildlife managements area, west-central Nevada, 1987-90_Part A. Water quality, sediment composition, and hydrogeochemical processes in STILLWATER and FERNLEY WILDLIFE MANAGEMENT AREAS: U.S. Geological Survey Water-Resources Investigations Report 92-4024-A, $65 \mathrm{p}$.

Lico, M.S., Hughes, J.L., and Welch, A.H., 1989, Hydrogeologic controls on the occurrence of radon-222 in ground water in WEST-CENTRAL NEVADA [abs.]: Geological Society of America, Abstracts with Programs, v. 21, no. 5, p. 106.
Lico, M.S., and Rowe, T.G., 1991, Radon in ground water of CARSON VALLEY, west-central Nevada, in Gundersen, L.C.S., and Wanty, R.B., eds., Field studies of radon in rocks, soils, and water: U.S. Geological Survey Bulletin 1971, p. 279-288.

Lico, M.S., Rowe, T.G., and Hoffman, R.J., 1989, U.S. Geological Survey study of irrigation drainage at wildlife management areas in CHURCHILL, LYON, and PERSHING COUNTIES, Nevada [abs.], in Foglesong, M.T., Bunch, R.L., and Myers, C.W., comps., Water resources for expanding State needs: Annual Conference, Nevada Water Resources Association, Carson City, Nev., March 1989, Program Information and Selected Abstracts, unpaginated.

Lico, M.S., Welch, A.H., and Hughes, J.L., 1986, Hydrologic, lithologic, and chemical data for sediment in the shallow alluvial aquifer at two sites near FALLON, Churchill County, Nevada, 1984-85: U.S. Geological Survey Open-File Report 86-250, 43 p.

Lico, M.S., Welch, A.H., and Hughes, J.L., 1987, Geochemistry of ground water in the shallow alluvial aquifer, CARSON DESERT, western Nevada, in Averett, R.C., and McKnight, D.M., eds., Chemical quality of water and the hydrologic cycle: Chelsea, Mich., Lewis Publishers, p. 89-109.

Lico, M.S., Welch, A.H., Hughes, J.L., and Otton, J.K., 1986 , Geochemistry of ground water in a shallow alluvial aquifer, CARSON DESERT, north-western Nevada [abs.]: American Chemical Society, 8th Rocky Mountain Regional Meeting, Denver, Colo., p. A-11.

Livingston, Penn, 1941, Underground leakage from artesian wells in the LAS VEGAS area, Nevada: U.S. Geological Survey Water-Supply Paper 849-D, p. 147-173.

Loeltz, O.J., 1952, Ground-water conditions in the vicinity of The Strip, LAS VEGAS VALLEY, Clark County, Nevada: U.S. Geological Survey Open-File Report 52-93, 14 p.

Loeltz, O.J., 1953, Results of a pumping test of an artesian well near BATTLE MOUNTAIN, Lander County, Nevada: U.S. Geological Survey Open-File Report 53-158, 23 p. 
Loeltz, O.J., 1960, Source of water issuing from springs in ASH MEADOW VALLEY, Nye County, Nevada [abs.]: Geological Society of America Bulletin, v. 71, no. 12 , pt. 2 , p. 1917-1918.

Loeltz, O.J., 1963, Ground-water conditions in the vicinity of Lake Mead Base, LAS VEGAS VALLEY, Nevada: U.S. Geological Survey Water-Supply Paper 1669-Q, 17 p.

Loeltz, O.J., 1963, Hydraulic characteristics of aquifers penetrated by irrigation wells in the vicinity of ORO. VADA, Humboldt County, Nevada: U.S. Geological Survey Open-File Report.

Loeltz, O.J., and Eakin, T.E., 1953 [1954], Geology and water resources of SMITH VALLEY, Lyon and Douglas Counties, Nevada: U.S. Geological Survey Water-Supply Paper 1228, 89 p.

Loeltz, O.J., and Malmberg, G.T., 1961, The ground-water situation in NEVADA, 1960: Nevada Department of Conservation and Natural Resources, Water Resources - Information Report 1, 20 p.

Loeltz, O.J., and Phoenix, D.A., 1955, Geology and groundwater resources of BUENA VISTA VALLEY, Pershing County, Nevada: Nevada State Engineer, Water Resources Bulletin 13, 61 p.

Loeltz, O.J., Phoenix, D.A., and Robinson, T.W., 1949 , Ground water in PARADISE VALLEY, Humboldt County, Nevada: Nevada State Engineer, Water Resources Bulletin 10,61 p.

Maest, A.S., Wing, Rachel, Nordstrom, D.K., Welch, A.H., and Lico, M.S., 1986, The determination and preservation of dissolved arsenic species in high arsenic waters from FALLON, NV, and Mono Lake, CA [abs.]: Eos, American Geophysical Union Transactions, v. 67, no. 44 , p. 940 .

Malmberg, G.T., 1961, A summary of the hydrology of the LAS VEGAS ground-water basin, Nevada, with special reference to the available supply: Nevada Department of Conservation and Natural Resources, Water Resources Bulletin 18, 23 p.

Malmberg, G.T., 1964, Land subsidence in LAS VEGAS VALLEY, Nevada, 1935-63: Nevada Department of Conservation and Natural Resources Information Report 5, 10 p.
Malmberg, G.T., 1965, Available water supply of the LAS VEGAS ground-water basin, Nevada: U.S. Geological Survey Water-Supply Paper 1780, 116 p.

Malmberg, G.T., 1967, Hydrology of the valley-fill and carbonate-rock reservoirs, PAHRUMP VALLEY, Nevada-California: U.S. Geological Survey WaterSupply Paper 1832, 47 p.

Malmberg, G.T., and Eakin, T.E., 1962, Ground-water appraisal of SARCOBATUS FLAT and OASIS VALLEY, Nye and Esmeralda County, Nevada: Nevada Department of Conservation and Natural Resources, Ground-Water Resources - Reconnaissance Report 10, $39 \mathrm{p}$.

Malmberg, G.T., and Eakin, T.E., 1964, Relation of fluoride content to recharge and movement of ground water in OASIS VALLEY, southern Nevada: U.S. Geological Survey Professional Paper 475-D, p. 189-191.

Malmberg, G.T., and Worts, G.F., Jr., 1966, The effects of pumping on the hydrology of KINGS RIVER VALLEY, Humboldt County, Nevada, 1957-64: Nevada Department of Conservation and Natural Resources, Water Resources Bulletin 31, 57 p.

Maurer, D.K., 1984, Hydrogeology of CARSON VALLEY, Nevada, in Lintz, Joseph, Jr., ed., Western geological excursions [in conjunction with 1984 annual meetings of Geological Society of America and affiliated societies]: University of Nevada, Reno, Mackay School of Mines, v. 3, p. 127-129.

Maurer, D.K., 1984, Major structural features of EAGLE VALLEY, Nevada, in Lintz, Joseph, Jr., ed., Western geological excursions [in conjunction with 1984 annual meetings of Geological Society of America and affiliated societies]: University of Nevada, Reno, Mackay School of Mines, v. 3, p. 125-127.

Maurer, D.K., 1985, Gravity survey and depth to bedrock in CARSON VALLEY, Nevada-California: U.S. Geological Survey Water-Resources Investigations Report 84-4202, 20 p.

Maurer, D.K., 1986, Geohydrology and simulated response to ground-water pumpage in CARSON VALLEY, a river-dominated basin in Douglas County, Nevada, and Alpine County, California: U.S. Geological Survey Water-Resources Investigations Report 86-4328, 109 p. 
Maurer, D.K., 1988, Simulated changes in ground-water flow caused by hypothetical pumping in east CARSON VALLEY, Douglas County, Nevada: U.S. Geological Survey Open-File Report 87-765, 6 p.

Maurer, D.K., 1988, Simulated changes in ground-water flow caused by hypothetical pumping in southeastern CARSON CITY, Nevada: U.S. Geological Survey Open-File Report 87-769, 7 p.

Maurer, D.K., 1989, Water-level data for LAS VEGAS VALLEY, Clark County, Nevada, 1986-87: U.S. Geological Survey Open-File Report 88-200, 45 p.

Maurer, D.K., 1990, Development and application of a ground-water flow model in CARSON VALLEY, Nevada [abs.] in Nichols, Martha, Foglesong, M.T., and Topping, M.A., comps., Water-Liquid gold: Annual Conference, Nevada Water Resources Association, Carson City, Nev., February 1987, Program Information and Selected Abstracts, unpaginated.

*Maurer, D.K., 1992, Documentation of model input and output values for simulation of ground-water flow in CARSON VÁ LLEY, Douglas County, Nevada, and Alpine County, California: U.S. Geological Survey Open-File Report 91-537, 5 p. and diskette.

*Maurer, D.K., 1992, Hydrogeology of the GENOA quadrangle, Nevada: Nevada Bureau of Mines and Geology Urban Maps Series, Genoa Folio, Map 1Cf, scale $1: 24,000$.

*Maurer, D.K., 1993, Hydrogeologic setting and hydrologic data of the SMOKE CREEK DESERT Basin, Washoe County, Nevada, and Lassen County, California, water years 1988-90: U.S. Geological Survey Water-

Resources Investigations Report 93-4043, 45 p.

Maurer, D.K., and Fischer, J.M., 1988, Recharge to the EAGLE VALLEY ground-water basin by streamflow in VICEE CANYON, west-central Nevada: U.S. Geological Survey Water-Resources Investigations Report $88-4158,66 \mathrm{p}$.

*Maurer, D.K., and Moffatt, R.L., 1992, General hydrology of the VISTA quadrangle [Nevada]: Nevada Bureau of Mines and Geology Urban Maps Series, Vista Folio, Map 4Hf, scale 1:24,000.
Maurer, D.K., and Myers, C.M., 1988, Recharging the ground water in EAGLE VALLEY, west-central Nevada, by augmenting natural streamflow in VICEE CANYON: U.S. Geological Survey Open-File Report 88-487, 2 p. (Water Fact Sheet).

Maurer, D.K., and Timian-Palmer, Dorothy, 1989, Recharge to the EAGLE VALLEY ground-water basin by streamflow in VICEE CANYON, west-central Nevada [abs.], in Foglesong, M.T., Bunch, R.L., and Myers, C.W., comps., Water resources for expanding State needs: Annual Conference, Nevada Water Resources Association, Carson City, Nev., March 1989, Program Information and Selected Abstracts, unpaginated.

Maxey, G.B., and Eakin, T.E., 1949, Ground water in WHITE RIVER VALLEY, White Pine, Nye, and Lincoln Counties, Nevada: Nevada State Engineer, Water Resources Bulletin 8, 59 p.

Maxey, G.B., and Jameson, C.H., 1945, Progress report on the ground water resources of the LAS VEGAS artesian basin, Nevada: U.S. Geological Survey Open-File Report, 36 p.

Maxey, G.B., and Jameson, C.H., 1946, Well data in LAS VEGAS and INDIAN SPRING VALLEYS, Nevada: Nevada State Engineer, Water Resources Bulletin 4, $128 \mathrm{p}$.

Maxey, G.B., and Jameson, C.F., 1948, Geology and water resources of LAS VEGAS, PAHRUMP, and INDIAN SPRING VALLEYS, Clark and Nye Counties, Nevada: Nevada State Engineer, Water Resources Bulletin 5, 292 p.

Maxey, G.B., and Robinson, T.W., 1947, Ground water in LAS VEGAS, PAHRUMP, and INDIAN SPRING VALLEYS, Nevada (a summary): Nevada State Engineer, Water Resources Bulletin 6, 23 p.

McBeth, P.E., Jr., 1986, Hydrogeologic significance of LANDSAT thematic mapper lineament analyses in the GREAT BASIN: University of Nevada, Reno, unpublished M.S. thesis, $133 \mathrm{p}$.

McBeth, P.E., Jr., and Plume, R.W., 1986, Geophysical exploration of the SOUTHERN NEVADA carbonate terrain: Nevada Water Conference, Las Vegas, February 1986, Poster-Session Display.

Meder, J.L., 1984, Human history and water use in the CARSON and TRUCKEE RIVER area, in Lintz, Joseph, Jr., ed., Westein geological excursions [in conjunction 
with 1984 annual meetings of Geological Society of American and affiliated societies]: University of Nevada, Reno, Mackay School of Mines, v. 3, p. 130134.

Meinzer, O.E., 1916, Ground water in BIG SMOKY VALLEY, Nevada, in Contributions to the hydrology of the United States, 1915: U.S. Geological Survey WaterSupply Paper 375, p. 85-116.

Meinzer, O.E., 1917, Geology and water resources of BIG SMOKY, CLAYTON, and ALKALI SPRING VALLEYS, Nevada: U.S. Geological Survey Water-Supply Paper 423, $167 \mathrm{p}$.

Mendenhall, W.C., 1909, Some desert watering places in southeastern California and SOUTHWESTERN NEVADA: U.S. Geological Survey Water-Supply Paper 224, $98 \mathrm{p}$.

Metzger, D.G., and Loeltz, O.J., 1973, Geohydrology of the NEEDLES area, Arizona, California, and Nevada: U.S. Geological Survey Professional Paper 486-J, 54 p.

*Meyer, D.F., and Berger, D.L., 1992, Flood and related debris-flow hazards, GENOA quadrangle [Nevada]: Nevada Bureau of Mines and Geology Urban Maps Series, Genoa Folio, Map 1Cl, scale 1:24,000.

*Meyer, D.F., and Berger, D.L., 1992, Flood and related debris hazards in the GENOA quadrangle, west-central Nevada: Nevada Bureau of Mines and Geology OpenFile Report 92-2, 22 p.

Mifflin, M.D., and Harrill, J.R., 1981, Hydrogeologic characteristics of the GREAT BASIN [abs.]: Geological Society of America, Abstracts with Programs, v. 13, no. 7.

Moore, D.O., 1965, A method of estimating mean runoff from ungaged basins in mountainous regions [abs.]: American Geophysical Union Transactions, v. 46, no. 3 .

Moore, D.O., 1968, Estimating mean runoff in ungaged semiarid areas: Nevada Department of Conservation and Natural Resources, Water Resources Bulletin 36, $11 \mathrm{p}$.

Moore, D.O., 1970, A proposed streamflow data program for NEVADA: Nevada Department of Conservation and Natural Resources, Water Resources Bulletin 40, 23 p.
Moore, D.O., 1974, Estimating flood discharges in NEVADA using channel-geometry measurements: Nevada Highway Department Hydrology Report 1, $43 \mathrm{p}$.

Moore, D.O., 1976, Estimating peak discharges from small drainages in NEVADA according to basin areas within elevation zones: Nevada Highway Department Hydrology Report 3,17 p.

Moore, D.O., and Eakin, T.E., 1968, Water-resources appraisal of the SNAKE RIVER BASIN in Nevada: Nevada Division of Water Resources, Reconnaissance Report 48, 103 p.

Moosburner, Otto, 1976, Flood investigations in NEVADA through 1975 water year, progress report 15: U.S. Geological Survey Open-File Report, 87 p.

Moosburner, Otto, 1977, Flood investigations in NEVADA through 1975 water year, progress report 16: U.S. Geological Survey Open-File Report, $90 \mathrm{p}$.

Moosburner, Otto, 1978, Flood investigations in NEVADA through 1977 water year-progress report 17: U.S. Geological Survey Open-File Report 78-610, 90 p.

Moosburner, Otto, 1981, Potential flood and debris hazards at COTTONWOOD COVE, Lake Mead National Recreation Area, Clark County, Nevada: U.S. Geological Survey Open-File Report 80-1216, 11 p.

Moosburner, Otto, 1986, NEVADA surface-water resources, in Moody, D.W., Chase, E.B., and Aronson, D.A., comps., National water summary 1985-Hydrologic events and surface-water resources: U.S. Geological Survey Water-Supply Paper 2300, p. 323-328.

Moosburner, Otto, 1988, Potential flood and debris hazards at KATHERINE LANDING and TELEPHONE COVE, Lake Mead National Recreation area, Mohave County, Arizona: U.S. Geological Survey WaterResources Investigations Report 87-4081, 19 p.

Moosburner, Otto, and Harrill, J.R., 1985, NEVADA ground-water resources, in National Water Summary 1984-Hydrologic events, selected water-quality trends, and ground-water resources: U.S. Geological Survey Water-Supply Paper 2275, p. 297-302.

Moosburner, Otto, Williams, R.P., James, John, and Turnipseed, Michael, 1991, NEVADA floods and droughts, in Paulson, R.W., Chase, E.B., Roberts, R.S., and Moody, D.W., comps., National water summary, 
1988-89-Hydrologic events and floods and droughts: U.S. Geological Survey Water-Supply Paper 2375, p.385-392.

Morgan, D.S., 1982, Hydrogeology of the STILLWATER geothermal area, Churchill County, Nevada: U.S. Geological Survey Open-File Report 82-345, 95 p.

Morgan, D.S., and Fischer, J.M., 1984, Unsaturated zone instrumentation in coarse alluvial deposits of the AMARGOSA DESERT near BEATTY, Nevada [abs.]: Second National Symposium and Exposition on Ground-Water Instrumentation, Las Vegas, Nev., April 1984, Conference Program.

Morgan, D.S., and Fischer, J.M., 1984, Unsaturated-zone instrumentation in coarse alluvial deposits of the AMARGOSA DESERT near BEATTY, Nevada, in Proceedings of Sixth Annual Participants' Information Meeting-U.S. Department of Energy Low-Level Waste Management Program: Available from National Technical Information Service, U.S. Department of Commerce, Springfield, VA 22161, CONF-8409115, p. 617-630.

Morros, P.G., and Shamberger, H.A., 1989, Evolution of water laws in NEVADA and the role of the Office of State Engineer [abs.], in Davis, F.E., ed., Contributed papers and abstracts for the Conference on WaterLaws and management: American Water Resources Association, Tampa, Fla., September 1989, p. 4B-5.

*Nichols, W.D., 1982, BEATTY, Nevada, in Schneider, Robert, Roseboom, E.H., Jr., and Robertson, J.B., and Stevens, P.R., eds., U.S. Geological Survey Research in radioactive waste disposal-Fiscal year 1979: U.S. Geological Survey Circular 847, p. 62-63.

Nichols, W.D., 1987, Geohydrology of the unsaturated zone at the burial site for low-level radioactive waste near BEATTY, Nye County, Nevada: U.S. Geological Survey Water-Supply Paper 2312, $57 \mathrm{p}$.

Nichols, W.D., 1988, Drought duration and frequency in the north-central GREAT BASIN, 1600-1982, and implications for water supply: Symposium on Water-Use Data for Water Resources Management, American Water Resources Association, Tucson, Ariz., August 1988, p. $479-485$.

*Nichols, W.D., 1990, The significance of climate in southern NEVADA for the shallow burial of low-level radioactive wastes: LaGrange, Ill., American $\mathrm{N}\lrcorner$ clear
Society, Topical on Nuclear Waste Isolation in the Unsaturated Zone, Proceedings, Las Vegas, Nev., September 1989, p. 93-98.

*Nichols, W.D., 1992, Energy budgets and resistances to energy transport in sparsely vegetated rangeland: Agricultural and Forest Meteorology, v. 60, p. 221-247.

*Nichols, W.D., 1992, Measuring and modeling radiation and energy budgets in sparse-canopy rangelands [abs.]: Eos, American Geophysical Union Transactions, v. 73, no. 43 , p. 237.

*Nichols, W.D., 1992, The uncertainty of water budget estimates in the GREAT BASIN, in Herrmann, Raymond, ed., Managing water resources during global change: 28th Annual Conference and Symposium, American Water Resources Association, Reno, Nev., November 1992, Proceedings, p. 309-317.

*Nichols, W.D., 1993, Estimating discharge of shallow groundwater by transpiration from greasewood in the northern GREAT BASIN: Water Resources Research, v. 29 , no. 8 , p. $2771-2778$.

Nichols, W.D., and Akers, J.P., 1985, Water-level declines in the AMARGOSA VALLEY area, Nye County, Nevada, 1962-84: U.S. Geological Survey WaterResources Investigations Report 85-4273, 7 p.

Nichols, W.D., and Davis, L.E., 1979, Data on ground-water resources of the SPRING MOUNTAINS area, Toiyabe National Forest, Nevada: U.S. Geological Survey. Open-File Report 79-1638, 16 p.

Nowlin, J.O., 1976, A preliminary evaluation of the chemical character of water near the northwest shore of TOPAZ LAKE, Douglas County, Nevada: U.S. Geological Survey Open-File Report 76-419, 14 p.

Nowlin, J.O., 1982, Ground-water levels and water quality in an area near TOPAZ LAKE, Douglas County, Nevada: U.S. Geological Survey Open-File Report 802046, 76 p.

Nowlin, J.O., 1986, Ground-water quality in NEVADA-A proposed monitoring program: U.S. Geological Survey Open-File Report 78-768, 236 p.

Nowlin, J.O., 1987, Documentation for a digital computer model of nutrient and dissolved-oxygen transport in the TRUCKEE RIVER and TRUCKEE CANAL downstream from Reno, Nevada: U.S. Geological Survey Open-File Report 87-554, 181 p. 
Nowlin, J.O., 1987, Modeling nutrient and dissolved-oxygen transport in the TRUCKEE RIVER and TRUCKEE CANAL downstream from Reno, Nevada: U.S. Geological Survey Water-Resources Investigations Report 87-4037, $487 \mathrm{p}$.

Nowlin, J.O., Brown, W.M., III, Smith, L.H., and Hoffman, R.J., 1980, Planning and design of studies for riverquality assessment in the TRUCKEE and CARSON RIVER BASINS, California and Nevada: U.S. Geological Survey Open-File Report 80-435, 75 p.

Olmsted, F.H., Glancy, P.A., Harrill, J.R., Rush, F.E., and Van Denburgh, A.S., 1973, Sources of data for evaluation of selected geothermal areas in NORTHERN and CENTRAL NEVADA: U.S. Geological Survey Water-Resources Investigations Report 73-212, 78 p.

Olmsted, F.H., Glancy, P.A., Harrill, J.R., Rush, F.E., and Van Denburgh, A.S., 1975, Preliminary hydrogeologic appraisal of selected hydrothermal systems in NORTHERN and CENTRAL NEVADA: U.S. Geological Survey Open-File Report 75-56, 360 p.

Olmsted, F.H., and Rush, F.E., 1987, Hydrogeologic reconnaissance of the BEOWAWE Geysers geothermal area, Nevada: Geothermics, v. 16, no. 1, p. 27-46.

Olmsted, F.H., Welch, A.H., and Ingebritzen, S.E., 1986, Shallow subsurface temperature surveys in the BASIN AND RANGE PROVINCE, U.S.A.-I. Review and evaluation: Geothermics, v. 15, no. 3, p. 251-265.

Olmsted, F.H., Welch, A.H., Van Denburgh, A.S., and Ingebritzen, S.E., 1984, Geohydrology, aqueous geochemistry, and thermal regime of the SODA LAKES and UPSAL HOGBACK geothermal systems, Churchill County, Nevada: U.S. Geological Survey WaterResources Investigations Report 84-4054, 166 p.

*Pabst, M.E., Beck, D.A., Glancy, P.A., and Johnson, J.A., 1993, Streamflow and selected precipitation data for YUCCA MOUNTAIN and vicinity, Nye County, Nevada, water years 1983-85: U.S. Geological Survey Open-File Report 93-438, 66 p.

Phoenix, D.A., 1948, Geology and ground water in the MEADOW VALLEY WASH drainage area, above the vicinity of Caliente, Nevada: Nevada State Engineer, Water Resources Bulletin 7, 117 p.

Phoenix, D.A., 1949, Geology of CLEAR CREEK dam site, Ormsby and Douglas Counties, Nevada: U.S. Geological Survey Open-File Report 49-97, 5 p.
Phoenix, D.A., 1949, Ground-water conditions in the vicinity of TONOPAH, Nye County, Nevada: U.S. Geological Survey Open-File Report 49-98, 12 p.

Phoenix, D.A., 1949, Results and description of test drilling in ARGENTA SWAMP near BATTLE MOUNTAIN, Nevada: U.S. Geological Survey Open-File Report 49. $99,11 \mathrm{p}$.

Phoenix, D.A., 1950, Ground-water in the AUSTIN area, Lander County, Nevada: U.S. Geological Survey Open-File Report 50-91, 21 p.

Plume, R.W., 1984, Use of aeromagnetic data to define some properties of a carbonate-rock aquifer in EASTERN NEVADA [abs.]: Geological Society of America, Abstracts with Programs, v. 16, no. 6, p. 624.

Plume, R.W., 1985, Geologic features that control regional ground-water movement in the EASTERN GREAT BASIN, Nevada and Utah [abs.]: Geological Society of America, Abstracts with Programs, v. 17, no. 7, p. 691.

Plume, R.W., 1985, Ground-water resources in KYLE and LEE CANYONS, SPRING MOUNTAINS, Clark County, Nevada: U.S. Geological Survey Open-File Report 84-438, 47 p.

Plume, R.W., 1988, Geologic features that affect the movement of recharge to ground-water basins adjacent to the central EGAN RANGE, White Pine County, Nevada [abs.]: Geological Society of America, Abstracts with Programs, v. 20, no. 3, p. 221.

Plume, R.W., 1988, Use of aeromagnetic data to define boundaries of a carbonate-rock aquifer in EASTCENTRAL NEVADA, in Subitzky, Seymour, ed., Selected papers in the hydrologic sciences: U.S. Geological Survey Water-Supply Paper 2330, p. 1-10.

Plume, R.W., 1989, Ground-water conditions in LAS VEGAS VALLEY, Clark County, Nevada-Part 1, Hydrogeologic framework: U.S. Geological Survey Water-Supply Paper 2320-A, 15 p.

Plume, R.W., and Carlton, S.M., 1988, Hydrogeology of the GREAT BASIN region of Nevada, Utah, and adjacent states: U.S. Geological Survey Hydrologic Investigations Atlas HA-694-A, 1 sheet, scale 1:1,000,00.

*Plume, R.W., and Stone, W.J., 1992, Hydrogeologic setting of the CARLIN TREND, northeastern Nevada: Society for Mining, Metallurgy, and Exploration, Inc., Preprint Number 92-27, $6 \mathrm{p}$. 
Prudic, D.E., and Dennehy, K.F., 1990, Induced changes in hydrology at low-level radioactive waste repository sites, in Bedinger, M.S., and Stevens, P.R., eds., Safe disposal of radionuclides in low-level radioactive waste repository sites-Low-level radioactive-waste disposal workshop, U.S. Geological Survey, July 11-16, 1987 , Big Bear Lake, Calif., Proceedings: U.S. Geological Survey Circular 1036, p. 2-4.

*Prudic, D.E., Harrill, J.R., and Burbey, T.J., 1993, Conceptual evaluation of regional ground-water flow in the carbonate-rock province of the GREAT BASIN, Nevada, Utah, and adjacent states: U.S. Geological Survey Open-File Report 93-170 (revision of Open-File Report 90-560), $103 \mathrm{p}$.

Pumphrey, H.L., 1955, Water-power resources in upper CARSON RIVER BASIN, California-Nevada: U.S. Geological Survey Water-Supply Paper 1329-A, 29 p.

Pupacko, Alex, 1991, Potential effects of climate change on the surface-water resources of the CARSON, American, and TRUCKEE RIVER BASINS-A study in progress: Abstracts on Climate Variability of the Eastern North Pacific and Western North America, 8th Annual PACLIM Workshop, Pacific Grove, Calif., March 1991, p. 23-24.

Pupacko, Alex, 1991, Preliminary investigation for characterization of drought and streamflow in the western GREAT BASIN-Distinguishing climate change from natural variability, in Kirby, W.H., and Tan, W.Y., comps., Proceedings of the United States-People's Republic of China Bilateral Symposium on Droughts and Arid-Region Hydrology, September 16-20, 1991, Tucson, Arizona: U.S. Geological Survey Open-File Report 91-244, p. 73-78.

*Pupacko, Alex, 1992, Potential effects of climate change on a windward and on a leew'ard drainage basin in the northern SIERRA NEVADA [abs.]: 9th Annual Pacific Climate Workshop (PACLIM), Asilomar, Calif., April 1992, Abstracts, p. 10.

*Pupacko, Alex, 1992, Streamflow variability in the LAKE TAHOE BASIN, California-Nevada [abs.], in Herrmann, Raymond, ed., Managing water resources during global change: 28th Annual Conference, American Water Resources Association, Reno, Nev., November 1992, Abstracts, p. 59.

*Pupacko, Alex, 1993, Potential effects of climate change on the surface-water resources of the CARSON, American, and TRUCKEE RIVER BASINS [abs.], in
Kelmelis, J.A., and Snow, Mitchell, eds., Proceedings of the U.S. Geological Survey Global Change Research Forum, Herndon, Virginia, March 18-20, 1991: U.S. Geological Survey Circular 1086, p. 107.

*Pupacko, Alex, 1993, Variations in northern SIERRA NEVADA streamflow-Implications of climate change: Water Resources Bulletin, v. 29, no. 2, p. 283290.

*Pupacko, Alex, Dettinger, M.D., Duell, L.F., Jeton, A.E., and Smith, J.L., 1992, Potential effects of climate change on surface-water resources of two high mountain watersheds in the western United States: JapanU.S. Committee on Hydrology, Water Resources, and Global Climate Change, JUCHWR Publication No. 1, Proceedings, Tsukuba, Japan, February 1992, p. 275286.

Pupacko, Alex, La Camera, R.J., Riek, M.M., and Swartwood, J.R., 1989, Water resources data, NEVADA, water year 1987: U.S. Geological Survey Water-Data Report NV-87-1, 256 p.

Pupacko, Alex, La Camera, R.J., Riek, M.M., and Swartwood, J.R., 1989, Water resources data, NEVADA, water year 1988: U.S. Geological Survey Water-Data Report NV-88-1, $271 \mathrm{p}$.

Pupacko, Alex, La Camera, R.J., Riek, M.M., and Wood, D.B., 1988, Water resources data, NEVADA, water year 1986: U.S. Geological Survey Water-Data Report NV-86-1, $263 \mathrm{p}$.

Pupacko, Alex, Van Gordon, L.C., Swartwood, J.R., and Collins, R.P., 1990, Water resources data, NEVADA, water year 1989: U.S. Geological Survey Water-Data Report NV-89-1, 342 p.

Pupacko, Alex, Wood, D.B., and Williams, R.P., 1990, Geohydrologic data for selected springs in EASTERN NEVADA through 1982, with emphasis on WHITE PINE COUNTY: U.S. Geological Survey Open-File Report 88-712, 45 p.

Purtyman, W.D., Harrill, J.R., and Rush, F.E., 1969, Geologic data for U20U satellite holes \#1, \#2, \#3, and \#4 and studies of the orientation of joints in the Thirsty Canyon Tuff, Area 20, PAHUTE MESA, Nevada Test Site: U.S. Geological Survey Open-File Report, 19 p. 
Rantz, S.E., and Eakin, T.E., 1972, A summary of methods for the collection and analysis of basic hydrologic data for arid regions: U.S. Geological Survey Open-File Report 72-305, 280 p.

Rantz, S.E., and Moore, A.M., 1965, Floods of December 1964 in far western states: U.S. Geological Survey Open-File Report 65-131, 112 p.

Riggs, H.C., and Moore, D.O., 1965, A method of estimating mean runoff from ungaged basins in mountainous regions in Geological Survey Research 1965: U.S. Geological Survey Professional Paper 525-D, p. 199 202.

Robbins, S.L., Prudic, D.E., Schaefer, D.H., and Clutsom, F.G., 1985, Principal facts and density estimates for borehole gravity stations in three water wells located in DIXIE and PARADISE VALLEYS, Nevada: U.S. Geological Survey Open-File Report 85-426, 20 p.

Robinson, T.W., 1949, Ground water in NEVADA, in Industrial minerals: Colorado School of Mines Quarterly, v. 45 , no. 4 B, p. $33-38$.

Robinson, T.W., 1951, Ground water for Indian Service Hospital at SCHURZ, Nevada: U.S. Geological Survey Open-File Report 51-146, 11 p.

Robinson, T.W., 1952, Phreatophytes and their relation to water in western UNITED STATES: American Geophysical Union Transactions, v. 33, no. 1, p. 57-61.

Robinson, T.W., 1952, Water thieves: Chemurgic Digest, v. 11 , no. 10 , p. 12-15.

Robinson, T.W., 1953, BIG SMOKY VALLEY, Nevada, in Subsurface facilities of water management and patterns of supply-Type area studies: U.S. Congress, House Committee on Interior and Insular Affairs, v. 4, ch. 8 , p. 132-146.

Robinson, T.W., and Fredericks, J.C., 1946, Ground water in LOVELOCK VALLEY, Nevada: Nevada State Engineer, Water Resources Bulletin 2, 25 p.

Robinson, T.W., Loeltz, O.J., and Phoenix, D.A., 1948, Ground water in GRASS VALLEY and adjacent portions of the HUMBOLDT RIVER VALLEY, Pershing and Humboldt Counties, Nevada: U.S. Geological Survey Open-File Report, 95 p.
Robinson, T.W., Loeltz, O.J., and Poole, J.L., 1951, Ground water in the vicinity of VERDI, Washoe County, Nevada: U.S. Geological Survey Open-File Report.

Robinson, T.W., Maxey, G.B., Fredericks, J.G., and Jameson, C.H., 1947, Water levels and artesian pressure in wells in LAS VEGAS VALLEY and in other valleys in Nevada, 1913-1945: Nevada State Engineer, Water Resources Bulletin 3, 77 p.

Robinson, T.W., and Phoenix, D.A., 1948, Ground water in SPANISH SPRING and SUN VALLEYS, Washoe County, Nevada: U.S. Geological Survey Open-File Report.

Rockwell, G.L., 1990, Surface-water hydrology of HONEY LAKE VALLEY, Lassen County, California, and Washoe County, Nevada: U.S. Geological Survey Open-File Report 90-177, 2 sheets.

Rowe, T.G., 1989, Mercury and selenium concentrations in surface water, bottom sediment, and biota, STILLWATER WILDLIFE MANAGEMENT AREA and vicinity, Churchill County, Nevada [abs.], in Pederson, G.L., and Smith, M.M., comps., U.S. Geological Survey Second National Symposium on Water QualityAbstracts of the Technical Sessions, Orlando, Florida, November 12-17, 1989: U.S. Geological Survey OpenFile Report 89-409, p. 80.

*Rowe, T.G., 1993, Streamflow, sediment, and nutrient data for two streams in the INCLINE VILLAGE area of the Lake Tahoe Basin, Nevada, during water years 1988-92: Nevada Water Resources Association, Nevada Water Conference, Reno, February 1993, Abstracts of Presented Papers and Posters, p. 26.

Rowe, T.G., and Hoffman, R.J., 1990, Wildlife kills in the CARSON SINK, western Nevada, winter of 1986-87, in Carr, J.E., Chase, E.B., Paulson, R.W., and Moody, D.W., comps., National water summary 1987-Hydrologic events and water supply and use: U.S. Geological Survey Water-Supply Paper 2350, p. 37-40.

Rowe, T.G., Lico, M.S., Hallock, R.J., Maest, A.S., and Hoffman, R.J., 1991, Physical, chemical, and biological data for detailed study of irrigation drainage in and near STILLWATER, FERNLEY, and HUMBOLDT WILDLIFE MANAGEMENT AREAS, and CARSON LAKE, west-central Nevada, 1987-89: U.S. Geological Survey Open-File Report 91-185, 199 p. 
Rush, F.E., 1964, Ground-water appraisal of the MEADOW VALLEY area, Lincoln and Clark Counties, Nevada: Nevada Department of Conservation and Natural Resources, Ground-Water Resources - Reconnaissance Report 27, 43 p.

Rush, F.E., 1967, Water-resources appraisal of WASHOE VALLEY, Nevada: Nevada Department of Conservation and Natural Resources, Water Resources - Reconnaissance Report 41, $39 \mathrm{p}$.

Rush, F.E., 1968a, Index of hydrographic areas in NEVADA: Nevada Division of Water Resources, Information Report 6, $38 \mathrm{p}$.

Rush, F.E., 1968, Water-resources appraisal of CLAYTON VALLEY-STONEWALL FLAT area, Nevada and California: Nevada Department of Conservation and Natural Resources, Water Resources - Reconnaissance Report 45, 54 p.

Rush, F.E., 1968, Water-resources appraisal of THOU. SAND SPRINGS VALLEY, Elko County, Nevada: Nevada Division of Water Resources, Reconnaissance Report 47,61 p.

Rush, F.E., 1968, Water-resources appraisal of the LOWER MOAPA-LAKE MEAD area, Clark County, Nevada: Nevada Division of Water Resources, Reconnaissance Report 50,66 p.

Rush, F.E., 1970, Hydrologic regimen of WALKER LAKE, Mineral County, Nevada: U.S. Geological Survey Hydrologic Investigations Atlas HA-415, scale $1: 62,500$.

Rush, F.E., 1971, Regional ground-water systems in the NEVADA TEST SITE area, Nye, Lincoln, and Clark Counties, Nevada: Nevada Division of Water Resources, Reconnaissance Report 54, 25 p.

Rush, F.E., 1972, Bathymetric reconnaissance of BIG and LITTLE WASHOE LAKES, Washoe County, Nevada: Nevada Department of Conservation and Natural Resources, Water Resources - Information Report 10,1 sheet.

Rush, F.E., 1972, Hydrologic reconnaissance of BIG and LITTLE SODA LAKES, Churchill County, Nevada: Nevada Department of Conservation and Natural Resources, Water Resources - Information Report 11, 1 sheet.
Rush, F.E., 1973, Bathymetric reconnaissance of LAKE TAHOE, Nevada and California: Nevada Division of Water Resources, Information Report 17, 1 map.

Rush, F.E., 1974, Static ground water levels of NEVADA: Nevada Division of Water Resources map, scale 1:750,000, 1 sheet.

Rush, F.E., 1975, Hydrologic map, WASHOE CITY quadrangle: Nevada Bureau of Mines and Geology Urban Maps Series, Washoe City Folio, Map 5Af, scale 1:24,000.

Rush, F.E., 1976, Water requirement and efficiency of sprinkler irrigation of alfalfa, SMITH VALLEY, NevadaA case history: Nevada Division of Water Resources, Information Report 24, 10 p.

Rush, F.E., and Eakin, T.E., 1963, Ground-water appraisal of LAKE VALLEY in Lincoln and White Pine Counties, Nevada: Nevada Department of Conservation and Natural Resources, Ground-Water Resources - Reconnaissance Report 24, 29 p.

Rush, F.E., and Everett, D.E., 1964, Ground-water appraisal of MONITOR, ANTELOPE, and KOBEH VALLEYS, Nevada: Nevada Department of Conservation and Natural Resources, Ground-Water Resources Reconnaissance Report 30, 42 p.

Rush, F.E., and Everett, D.E., 1966, Water-resources appraisal of the HUNTINGTON VALLEY area, Elko and White Pine Counties, Nevada: Nevada Department of Conservation and Natural Resources, Reconnaissance Report 35, $37 \mathrm{p}$.

Rush, F.E., and Everett, D.E., 1966, Water-resources appraisal of LITTLE FISH LAKE, HOT CREEK, and LITTLE SMOKY VALLEYS, Nevada: Nevada Department of Conservation and Natural Resources, Reconnaissance Report 38, 39 p.

Rush, F.E., and Glancy, P.A., 1967, Water-resources appraisal of the WARM SPRINGS-LEMMON VALLEY area, Washoe County, Nevada: Nevada Department of Conservation and Natural Resources, Water Resources - Reconnaissance Report 43, 70 p.

Rush, F.E., and Hill, V.R., 1972, Bathymetric reconnaissance of TOPAZ LAKE, Nevada and California: Nevada Division of Water Resources, Information Report 12, 1 plate. 
Rush, F.E., and Huxel, C.J., Jr., 1966, Ground-water appraisal of the ELDORADO-PIUTE VALLEY area, Nevada and California: Nevada Department of Conservation and Natural Resources, Water Resources Reconnaissance Report 36, 30 p.

Rush, F.E., and Katzer, T.L., 1973, Water-resources appraisal of FISH LAKE VALLEY, Nevada and California: Nevada Division of Water Resources, Reconnaissance Report 58, 70 p.

Rush, F.E., and Kazmi, S.A.T., 1965, Water resources appraisal of SPRING VALLEY, White Pine and Lincoln Counties, Nevada: Nevada Department of Conservation and Natural Resources, Water Resources Reconnaissance Report 33, 39 p.

Rush, F.E., and Rice, B.L., 1972, Bathymetric reconnaissance of RYE PATCH RESERVOIR and the PITT. TAYLOR RESERVOIRS, Pershing County, Nevada: Nevada Division of Water Resources, Information Report 13, 1 map.

Rush, F.E., and Schroer, C.V., 1970, Water resources of BIG SMOKY VALLEY, Lander, Nye, and Esmeralda Counties, Nevada: Nevada Division of Water Resources, Bulletin 41, 84 p.

Rush, F.E., and Schroer, C.V., 1976, Geohydrology of SMITH VALLEY, Nevada, with special reference to the water-use period, 1953-72: Nevada Division of Water Resources, Bulletin 43, 95 p.

Rush, F.E., Scott, B.R., Glancy, P.A., Katzer, T.L., and Ament, E.P., 1972, Bathymetric reconnaissance of MARLETTE and SPOONER LAKES, Washoe County and Carson City, Nevada: Nevada Division of Water Resources, Information Report 14, 1 map.

Rush, F.E., Scott, B.R., Van Denburgh, A.S., and Vasey, B.J., comps., 1971, State of NEVADA water resources and interbasin flows: Nevada Division of Water Resources map, scale 1:750,000.

Russell, I.C., 1885, Geologic history of LAKE LAHONTAN-A Quaternary lake in northwestern Nevada: U.S. Geological Survey Monograph 11, 288 p.

Savard, C.S., 1988, Hydrology of four watersheds in the carbonate-rock province, WHITE PINE COUNTY, Nevada [abs.]: 24th Annual Conference, American Water Resources Association, Milwaukee, Wis., November 1988, Program.
Savard, C.S., 1989, Contributing drainage-area size in carbonate-rock province basins, EAST-CENTRAL NEVADA [abs.], in Foglesong, M.T., Bunch, R.L., and Myers, C.W., comps., Water resources for expanding State needs: Annual Conference, Nevada Water Resources Association, Carson City, Nev., March 1989, Program Information and Selected Abstracts, unpaginated.

*Savard, C.S., and Crompton, E.J., 1993, Hydrologic data for EAST-CENTRAL NEVADA, water years 198288: U.S. Geological Survey Open-File Report 90-153, $128 \mathrm{p}$.

Savard, C.S., and Morgan, C.O., 1986, Radionuclide migration studies associated with underground nuclear weapon testing, NEVADA TEST SITE, Nevada: Nevada Water Conference, Las Vegas, February 1986, Poster-Session Display.

Schaefer, D.H., 1980, Water resources of the WALKER RIVER Indian Reservation, west-central Nevada: U.S. Geological Survey Open-File Report 80-427, 61 p.

Schaefer, D.H., 1983, Gravity survey of DIXIE VALLEY, west-central Nevada: U.S. Geological Survey OpenFile Report 82-111, 17 p.

Schaefer, D.H., 1986, Bouguer gravity anomalies, depth to bedrock, and shallow temperature in the HUMBOLDT HOUSE geothermal area, Pershing County, Nevada: U.S. Geological Survey Miscellaneous Investigations Map I-1701, 1 sheet.

Schaefer, D.H., 1988, Bouguer gravity anomaly maps of PARADISE, STAGECOACH, DIXIE, FAIRVIEW, and STINGAREE VALLEYS, northwestern Nevada: U.S. Geological Survey Geophysical Investigations Map GP-985, 1 sheet.

Schaefer, D.H., 1988, Gravity, depth to consolidated rock, and soil temperature in the ELKO area, northeastern Nevada: U.S. Geological Survey Miscellaneous Investigations Map I-1900, 1 sheet.

*Schaefer, D.H., 1993, Documentation of model input and output values for simulation of regional ground-water flow, CARBONATE-ROCK PROVINCE, Nevada, Utah, and adjacent states: U.S. Geological Survey Open-File Report 93-420 (revision of Open-File Report 91-479), 4 p. and diskette. 
*Schaefer, D.H., 1993, Hydrologic implications of measured changes in gravity during pumping at a carbonate-rock well near MOAPA, Clark County, Nevada: U.S. Geological Survey Water-Resources Investigations Report 93-4095, $11 \mathrm{p}$.

Schaefer, D.H., Duffrin, B.G., and Plume, R.W., 1986, Principal facts for gravity stations in PARADISE and STAGECOACH VALLEYS, Humboldt and Lyon Counties, Nevada: U.S. Geological Survey Open-File Report 85-694, 15 p.

Schaefer, D.H., and Maurer, D.K., 1980, Principal facts for gravity stations in LEMMON VALLEY, Washoe County, Nevada: U.S. Geological Survey Open-File Report 80-71, 9 p.

Schaefer, D.H., and Maurer, D.K., 1980, Principal facts for gravity stations in the BLACK ROCK DESERT, northwestern Nevada: U.S. Geological Survey OpenFile Report 80-577, $15 \mathrm{p}$.

Schaefer, D.H., and Maurer, D.K., 1981, Geophysical reconnaissance of LEMMON VALLEY, Washoe County, Nevada: U.S. Geological Survey Water-Resources Investigations Open-File Report 80-1123, 29 p.

Schaefer, D.H., and Maurer, D.K., 1981, Geophysical reconnaissance of LEMMON VALLEY, Nevada [abs.]: Eos, America Geophysical Union Transactions, v. 62, no. 45, p. $862-863$.

Schaefer, D.H., and Maurer, D.K., 1983, Bouguer gravity map of the western arm of the BLACK ROCK DESERT, northwestern Nevada: U.S. Geological Survey Geophysical Investigations Map GP-952, scale $1: 125,000$.

*Schaefer, D.H., Morris, T.M., and Dettinger, M.D., 1992, Hydrogeologic and geophysical data for selected wells and springs in the SHEEP RANGE area, Clark and Lincoln Counties, Nevada: U.S. Geological Survey Open-File Report 89-425, 26 p.

Schaefer, D.H., Thomas, J.M., and Duffrin, B.G., 1984, Principal facts for gravity stations in DIXIE, FAIRVIEW, and STINGAREE VALLEYS, Churchill and Pershing Counties, Nevada: U.S. Geological Survey Open-File Report 84-586, 15 p.
Schaefer, D.H., Welch, A.H., and Maurer, D.K., 1983, Geothermal resources of the western arm of the BLACK ROCK DESERT, northwestern Nevada-Part I, geology and geophysics: U.S. Geological Survey OpenFile Report 81-918, 37 p.

*Schaefer, D.H., and Whitney, Rita, 1992, Geological framework and ground-water conditions in basin-fill aquifers of the DAYTON VALLEY and CHURCHILL VALLEY hydrographic areas, western Nevada: U.S. Geological Survey Water-Resources Investigations Report 91-4072, $12 \mathrm{p}$.

Schroer, C.V., and Moosburner, Otto, 1978, NEVADA streamflow characteristics: Nevada Division of Water Resources, Information Report 28, 478 p.

Scott, B.R., Smales, T.J., Rush, F.E., and Van Denburgh, A.S., 1971, NEVADA's water resources: Nevada Division of Water Resources, Water for Nevada Report 3, $87 \mathrm{p}$.

Scott, W.B., 1990, Hydrologic activities of the U.S. Geological Survey in support of the Radionuclide Migration Program, NEVADA TEST SITE and vicinity, Nye County, Nevada, fiscal year 1987: U.S. Geological Survey Open-File Report 90-105, 13 p.

*Scott, W.B., 1991, NEVADA TEST SITE Weapons Testing Program, in Trask, N.J., and Stevens, P.R., eds., U.S. Geological Survey Research in radioactive waste disposal-Fiscal years 1986-90: U.S. Geological Survey Water-Resources Investigations Report 91-4084, p. 56-68.

*Scott, W.B., and Morgan, C.O., 1992, Hydrologic activities of the U.S. Geological Survey in support of the Radionuclide Migration Program, NEVADA TEST SITE, Nye County, Nevada, fiscal year 1986, in Jones, M.A., comp., Hydrology/Radionuclide Migration Program and related research activities, FY 1986 progress report (October 1, 1985-September 30, 1986): U.S. Department of Energy, DOE/NV-354, UC-700, p. 177-186.

*Seiler, R.L., 1993, NEVADA stream water quality, in Paulson, R.W., Chase, E.B., Williams, J.S., and Moody, D.W., comps., Hydrologic events and stream water quality: U.S. Geological Survey Water-Supply Paper 2400 , p. 379-385. 
*Seiler, R.L., 1993, Water level changes in the shallow aquifer near FALLON, Nevada: Nevada Water Resources Association, Nevada Water Conference, Reno, February 1993, Abstracts of Presented Papers and Posters, p. 10.

*Seiler, R.L., and Allander, K.K., 1993, Water-level changes and directions of ground-water flow in the shallow aquifer, FALLON area, Churchill County, Nevada: U.S. Geological Survey Water-Resources Investigations Report 93-4118, 74 p.

*Seiler, R.L., Ekechukwu, G.A., and Hallock, R.J., 1993, Reconnaissance investigation of water quality, bottom sediment, and biota associated with irrigation drainage in and near HUMBOLDT WILDLIFE MANAGEMENT AREA, Churchill and Pershing Counties, Nevada, 1990-91: U.S. Geological Survey WaterResources Investigations Report 93-4072, 115 p.

Seitz, H.R., Van Denburgh, A.S., and La Camera, R.J., 1982, Ground-water quality downgradient from copper-ore milling wastes at WEED HEIGHTS, Lyon County, Nevada: U.S. Geological Survey Open-File Report 801217,48 p.

Sertic, K.A., 1989, Chlorofluorocarbon compounds in ground water-A possible management tool [abs.], in Pederson, G.L., and Smith, M.M., comps., U.S. Geological Survey Second National Symposium on Water Quality-Abstracts of the Technical Sessions, Orlando, Florida, November 12-17, 1989: U.S. Geological Survey Open-File Report 89-409, p. 87.

Shamberger, H.A., 1962, A proposed ten-year cooperative water resources program between the State of Nevada and U.S. Geological Survey: Nevada Department of Conservation and Natural Resources, Water Resources - Information Report 4, 18 p.

Shamberger, H.A., 1972, The story of the water supply for the COMSTOCK: U.S. Geological Survey Professional Paper 779, 53 p.

Shamberger, H.A., 1972, The story of RAWHIDE, Mineral County, Nevada: Carson City, Nev., Nevada State Printing Office, Historic Mining Camps of Nevada no. $2,68 \mathrm{p}$.

Shamberger, H.A., 1972, The story of SEVEN TROUGHS, Pershing County, Nevada: Caldwell, Idaho, Caxton Printers, Historic Mining Camps of Nevada no. 3, 57 p.
Shamberger, H.A., 1973, The story of ROCHESTER, Pershing County, Nevada: Sparks, Nev., Western Printing \& Publishing Co., Historic Mining Camps of Nevada no. $4,65 \mathrm{p}$.

Shamberger, H.A., 1973, The story of FAIRVIEW, Churchill County, Nevada: Sparks, Nev., Western Printing \& Publishing Co., Historic Mining Camps of Nevada no. 5, $61 \mathrm{p}$.

Shamberger, H.A., 1974, The story of WONDER, Churchill County, Nevada: Sparks, Nev., Western Printing \& Publishing Co., Historic Mining Camps of Nevada no. $6,80 \mathrm{p}$.

Shamberger, H.A., 1975, The story of WEEP/2H, Esmeralda County, Nevada: Sparks, Nev., Western Printing \& Publishing Co., Historic Mining Camps of Nevada no. $7,89 \mathrm{p}$.

Shamberger, H.A., 1976, The story of SILVER PEAK, Esmeralda County, Nevada: Sparks, Nev., Western Printing \& Publishing Co., Historic Mining Camps of Nevada no. 8, $111 \mathrm{p}$.

Shamberger, H.A., 1978, The story of CANDELARIA and its neighbors, Esmeralda and Mineral County, Nevada: Sparks, Nev., Western Printing \& Publishing Co., Historic Mining Camps of Nevada no. 9, 199 p.

Shamberger, H.A., 1982, The story of GOLDFIELD, Esmeralda County, Nevada: Sparks, Nev., Western Printing \& Publishing Co., Historic Mining Camps of Nevada no. 10, 240 p.

Shamberger, H.A., 1991, Evolution of NEVADA's water laws, as related to the development and evaluation of the state's water resources, from 1866 to about 1960: Nevada Division of Water Resources, Bulletin 46, $100 \mathrm{p}$.

Sinclair, W.C., 1962, Ground-water resources of PINE FOREST VALLEY, Humboldt County, Nevada: Nevada Department of Conservation and Natural Resources, Ground-Water Resources - Reconnaissance Report 4, 22 p.

Sinclair, W.C., 1962, Ground-water resources of DESERT VALLEY, Humboldt and Pershing Counties, Nevada: Nevada Department of Conservation and Natural Resources, Ground-Water Resources - Reconnaissance Report 7, 23 p. 
Sinclair, W.C., 1962, Ground-water resources of HUALAPAI FLAT, Washoe, Pershing, and Humboldt Counties, Nevada: Nevada Department of Conservation and Natural Resources, Ground-Water Resources - Reconnaissance Report 11, $16 \mathrm{p}$.

Sinclair, W.C., 1963, Ground-water appraisal of the LONG VALLEY-MASSACRE LAKE region, Washoe County, Nevada: Nevada Department of Conservation and Natural Resources, Ground-Water Resources Reconnaissance Report 15, 19 p.

Sinclair, W.C., 1963, Ground-water appraisal of DUCK LAKE VALLEY, Washoe County, Nevada: Nevada Department of Conservation and Natural Resources, Ground-Water Resources - Reconnaissance Report 17, $19 \mathrm{p}$.

Sinclair, W.C., 1963, Ground-water appraisal of the BLACK ROCK DESERT area, northwestern Nevada: Nevada Department of Conservation and Natural Resources, Ground-Water Resources - Reconnaissance Report 20, $33 \mathrm{p}$.

Sinclair, W.C., 1963, Ground-water appraisal of PUEBLO VALLEY-CONTINENTAL LAKE region, Humboldt County, Nevada: Nevada Department of Conservation and Natural Resources, Ground-Water Resources Reconnaissance Report 22, 25 p.

Sinclair, W.C., and Loeltz, O.J., 1963, Ground-water conditions in the FERNLEY-WADSWORTH area, Churchill, Lyon, Storey, and Washoe Counties, Nevada: U.S. Geological Survey Water-Supply Paper 1619-AA, $22 \mathrm{p}$.

Smales, T.J., and Harrill, J.R., 1971, Estimated water use: Nevada Division of Water Resources, Water for Nevada Report 2, 32 p.

*Smith, J.L., 1992, Objective methods for watershed characterization using a geographic information system and remotely sensed data [abs.], in Herrmann, Raymond, ed., Managing water resources during global change: 28th Annual Conference, American Water Resources Association, Reno, Nev., Abstracts, p. 92.

Smith, J.L., Quinn, G.W., and Crompton, E.J., 1990, Use of Landsat data for identification and mapping of irrigated agricultural lands in FISH LAKE VALLEY, Nevada [abs.], in Nevada decision point-Which water course to the future?: Annual Conference, Nevada Water
Resources Association, Las Vegas, Nev., February 1990, Program Information and Abstracts, unpaginated.

Smith, L.H., 1980, Approximate relationships between river inflows and the lake level and dissolved-solids concentration of PYRAMID LAKE, Washoe County, Nevada: U.S. Geological Survey Open-File Report 82$80,5 \mathrm{p}$.

Smith, W.O., Vetter, C.P., Cummings, G.B., and others, 1960, Comprehensive survey of sedimentation in LAKE MEAD, 1948-49: U.S. Geological Survey Professional Paper 295, $254 \mathrm{p}$.

Stuart, W.T., 1955, Pumping test evaluates water problem at EUREKA, Nevada: Mining Engineering, v. 7, no. 2, p. 148-156.

Squires, R.R., and Young, R.L., 1984, Flood potential of FORTYMILE WASH and its principal southwestern tributaries, Nevada Test Site, southern Nevada: U.S. Geological Survey Water-Resources Investigations Report 83-4001, 33 p.

Taylor, L.H., 1902, Water storage in the TRUCKEE BASIN, California-Nevada: U.S. Geological Survey Water-Supply Paper 68, 90 p.

Thodal, C.E., 1989, Data on ground-water quality, CARSON VALLEY and TOPAZ LAKE areas, Douglas County, Nevada, for year ending September 1986: U.S. Geological Survey Open-File Report 88-453, 55 p.

*Thodal, C.E, 1992, Data on ground-water quality, CARSON VALLEY and TOPAZ LAKE areas, Douglas County, Nevada, for year ending September 1987: U.S. Geological Survey Open-File Report 90-146, 44 p.

*Thodal, C.E., 1992, Geophysical, hydrogeologic, and water-quality data for areas tributary to LAKE TAHOE in Douglas County and Carson City, Nevada, through 1987: U.S. Geological Survey Open-File Report 89-263, 32 p.

Thomas, C.A., and Lamke, R.D., 1962, Floods of February 1962 in southern Idaho and NORTHERN NEVADA: U.S. Geological Survey Circular 467, 30 p.

Thomas, H.E., 1954, First fourteen years of LAKE MEAD: U.S. Geological Survey Circular 346, 27 p. 
Thomas, J.M., 1988, Delineation of regional ground-water flow systems in SOUTHERN NEVADA using isotopic and chemical data [abs.]: Geological Society of America, Abstracts with Programs, v. 20, no. 7, p. A363.

*Thomas, J.M., 1993, Carbon-14 dating of ground water in carbonate-rock aquifers of SOUTHERN NEVADAA complex problem [abs.]: Geological Society of America, Abstracts with Programs, v. 25, no. 6, p. 90.

Thomas, J.M., Carlton, S.M., and Hines, L.B., 1989, Ground-water hydrology and simulated effects of development in SMITH CREEK VALLEY, a hydrologically closed basin in Lander County, Nevada: U.S. Geological Survey Professional Paper 1409-E, 57 p.

Thomas, J.M., and Hoffman, R.J., 1988, NEVADA groundwater quality, in Moody, D.W., Carr, Jerry, Chase, E.B., and Paulson, R.W., comps., National Water Summary 1986-Hydrologic events and ground-water quality: U.S. Geological Survey Water-Supply Paper 2325, p. 355-362.

Thomas, J.M., Lyles, B.F., and Carpenter, L.A., 1991, Chemical and isotopic data for water from wells, springs, and streams in carbonate-rock terrane of SOUTHERN and EASTERN NEVADA and southeastern California, 1985-88: U.S. Geological Survey Open-File Report $89-422,24 \mathrm{p}$.

Thomas, J.M., Mason, J.L., and Crabtree, J.D., 1986, Ground-water levels in the GREAT BASIN Region of Nevada, Utah, and adjacent states: U.S. Geological Survey Hydrologic Investigations Atlas 694-B, 2 sheets.

Thomas, J.M., Schaefer, D.H., and Dettinger, M.D., 1990, Use of geochemical data to trace ground-water flow, which could affect oil migration, in carbonate-rock aquifers of the EASTERN GREAT BASIN, Nevada and Utah [abs.], in Flanigan, D.M.H., Garside, L.J., and Hansen, Mike, eds., Oil fields and geology of the Pine Valley, Eureka County area, Nevada: Reno, Nev., Nevada Petroleum Society Inc., 1990 Fieldtrip Guidebook, $74 \mathrm{p}$.

Thomas, J.M., Welch, A.H., and Gunderson, L.S., 1990, Distribution and sources of radon-222 in ground water in the CARSON RIVER BASIN, western Nevada and eastern California, U.S.A. [abs.]: Eos, American Geophysical Union Transactions, v. 71, no. 43, p. 1305.
*Thomas, J.M., Welch, A.H., Lico, M.S., Hughes, J.L., and Whitney, Rita, 1993, Radionuclides in ground water of the CARSON RIVER BASIN, western Nevada and eastern California, U.S.A.: Applied Geochemistry, v. 8, no. 5, p. 447-471.

Thomas, J.M., Welch, A.H., and Preissler, A.M., 1985, Geochemical evolution of ground water in a hydrologically closed basin, northern BASIN AND RANGE PROVINCE, Nevada [abs.]: Practical Applications of Ground-Water Geochemistry Conference, Banff, Canada, June 1984, Conference Proceedings, p. 189.

Thomas, J.M., Welch, A.H., and Preissler, A.M., 1989, Geochemical evolution of ground water in SMITH CREEK VALLEY - A hydrologically closed basin in central Nevada, U.S.A.: Applied Geochemistry, v. 4, p. 493-510.

Thompson, T.H., Chappell, Richard, Harrill, J.R., and Welch, A.H., 1985, Maps showing distribution of dissolved solids and dominant chemical type in ground water, BASIN AND RANGE PROVINCE, Nevada: U.S. Geological Survey Water-Resources Investigations Report 83-4119-C, 11 p.

*Touray, K.S., Lowery, B., and Andraski, B.J., 1991, Soil water content, potential, availability as affected by soil erosion [abs.]: Agronomy Abstracts, American Society of Agronomy, 1991 Annual Meetings, Denver, Colo., October 1991, p. 343.

U.S. Department of the Interior, 1985, A proposed program to study the water resources of the carbonate-rock system of EASTERN and SOUTHERN NEVADA: U.S. Department of the Interior report, $14 \mathrm{p}$.

U.S. Geological Survey, 1954, Fioods of November-December 1950, in WESTERN NEVADA: U.S. Geological Survey Water-Supply Paper 1137-H, 59 p.

U.S. Geological Survey, 1962, Flood investigations in NEVADA, July 1, 1961, to August 16, 1962, first progress report: U.S. Geological Survey Open-File Report.

U.S. Geological Survey, 1962-65, Surface water records of NEVADA, 1961-64: Carson City, Nev., U.S. Geological Survey water-data reports (published annually).

U.S. Geological Survey, 1966-75, Water resources data for NEVADA, 1965-74: Carson City, Nev., U.i. Geological Survey water-data reports (published annually). 
U.S. Geological Survey, 1976-82, Water resources data, NEVADA, water years 1975-81: U.S. Geological Survey Water-Data Reports NV-75-1 to NV-81-1 (published annually).

U.S. Geological Survey, 1984, NEVADA water issues, in National water summary 1983-Hydrologic events and issues: U.S. Geological Survey Water-Supply Paper 2250, p. 166-168.

Van Denburgh, A.S., 1973, Mercury in the CARSON and TRUCKEE RIVER systems, Nevada: U.S. Geological Survey Open-File Report 73-352, 14 p.

Van Denburgh, A.S., 1981, Water resources of COLD SPRING VALLEY, a growing urban area northwest of Reno, Nevada: U.S. Geological Survey Open-File Report 80-1287, 79 p.

Van Denburgh, A.S., and Arteaga, F.E., 1985, Revised water budget for the FERNLEY area, west-central Nevada, 1979: U.S. Geological Survey Open-File Report 84$712,17 \mathrm{p}$.

Van Denburgh, A.S., and Glancy, P.A., 1970, Waterresources appraisal of the COLUMBUS SALT MARSH - SODA SPRING VALLEY area, Mineral and Esmeralda Counties, Nevada: Nevada Division of Water Resources, Reconnaissance Report 52, 66 p.

Van Denburgh, A.S., and Goerlitz, D.F., 1987, Mobility of nitrogen-bearing organic explosives wastes and related compounds in shallow ground water near HAW. THORNE, Nevada [abs.]: Geological Society of America, Abstracts with Programs, v. 19, no. 7, p. 875

Van Denburgh, A.S., Lamke, R.D., and Hughes, J.L., 1973, A brief water-resources appraisal of the TRUCKEE RIVER BASIN, western Nevada: Nevada Division of Water Resources, Reconnaissance Report 57, 122 p.

Van Denburgh, A.S., and Rush, F.E., 1974, Water-resources appraisal of RAILROAD and PENOYER VALLEYS, east-central Nevada: Nevada Division of Water Resources, Reconnaissance Report 60,61 p.

Van Denburgh, A.S., and Schaefer, D.H., 1986, Mobility of nitrogen-bearing explosives wastes in shallow ground water near HAWTHORNE, Nevada [abs.]: 152nd National Meeting, American Association for the Advancement of Science, Philadelphia, Pa., May 1986, Abstracts of Papers, p. 146.
Van Denburgh, A.S., Seitz, H.R., Durbin, T.J., and Harrill, J.R., 1982, Proposed monitoring network for groundwater quality, LAS VEGAS VALLEY, Nevada: U.S. Geological Survey Open-File Report 80-1286, 25 p.

Visher, F.N., 1957, Geology and ground-water resources ofQUINN RIVER VALLEY, Humboldt County, Nevada: Nevada State Engineer, Water Resources Bulletin 14, $56 \mathrm{p}$.

Walker, G.E., and Eakin, T.E., 1963, Geology and ground water of AMARGOSA DESERT, Nevada-California: Nevada Department of Conservation and Natural Resources, Ground-Water Resources - Reconnaissance Report 14, 45 p.

Waring, G.A., 1918, Ground water in REESE RIVER basin and adjacent parts of HUMBOLDT RIVER basin: U.S. Geological Survey Water-Supply Paper 425-D, p. 95-129.

Waring, G.A., 1921, Ground water in PAHRUMP, MESQUITE, and IVANPAH VALLEYS, Nevada and California, in Contributions to the hydrology of the United States: U.S. Geological Survey Water-Supply Paper 450 , p. $51-81$.

Welch, A.H., and Lico, M.S., 1986, Arsenic in shallow ground water beneath an irrigated pasture in WESTERN NEVADA [abs.]: Eos, American Geophysical Union Transactions, v. 67, no. 44, p. 941.

Welch, A.H., and Lico, M.S., 1988, Aqueous geochemistry of ground water with high concentrations of arsenic and uranium, CARSON RIVER BASIN, Nevada [abs.]: Chemical Geology, v. 70, no. 1/2, p. 19.

Welch, A.H., and Lico, M.S., 1988, Arsenic in an alluviallacustrine aquifer, CARSON DESERT, western Nevada, in Ragone, S.E., ed., U.S. Geological Survey program on toxic waste-Ground-water contamination, October 1985, proceedings: U.S. Geological Survey Open-File Report 86-481, p. E-13 - E-18.

Welch, A.H., Lico, M.S., and Hughes, J.L., 1986, Arsenic in groundwater of the western United States: Second Annual Canadian/American Conference on Hydrogeology, Hazardous Wastes in Ground Water-A Soluble Dilemma, Banff, Alberta, Canada, June 1985, p. 81-82.

Welch, A.H., Lico, M.S., and Hughes. J.L., 1988, Arsenic in ground water of the western United States: Ground Water, v. 26, no. 3, p. 333-347. 
Welch, A.H., and Olmsted, F.H., 1984, Geothermal systems of WESTERN NEVADA, in Lintz, Joseph, Jr., ed., Western geological excursions [in conjunction with 1984 annual meetings of Geological Society of America and affiliated societies]: University of Nevada, Reno, Mackay School of Mines, v. 3, p. 145-146.

Welch, A.H., and Plume, R.W., 1987, Water-quality assessment of the CARSON RIVER ground-water basin, Nevada and California-Project description: U.S. Geological Survey Open-File Report 87-104, 27 p.

Welch, A.H., Plume, R.W., Frick, E.A., and Hughes, J.L., 1989, Ground-water-quality assessment of the CARSON RIVER BASIN, Nevada and California-Analysis of available water-quality data through 1987: U.S. Geological Survey Open-File Report 89-382, 115 p.

Welch, A.H., and Preissler, A.M., 1986, Aqueous geochemistry of the BRADYS HOT SPRING geothermal area, Churchill County, Nevada, in Subitzky, Seymour, ed., Selected papers in the hydrologic sciences: U.S. Geological Survey Water-Supply Paper 2290, p. 17-36.

Welch, A.H., and Preissler, A.M., 1990, Geothermal resources of the western arm of the BLACK ROCK DESERT, northwestern Nevada-Part II, Aqueous geochemistry and hydrology: U.S. Geological Survey Water-Resources Investigations Report 87-4062, $91 \mathrm{p}$.

Welch, A.H., Sorey, M.L., and Olmsted, F.H., 1981, The hydrothermal system in southern GRASS VALLEY, Pershing County, Nevada: U.S. Geological Survey Open-File Report 81-915, 193 p.

Welch, A.H., Sorey, M.L., and Olmsted, F.H., 1983, Hydrology of the hydrothermal system in scuthern GRASS VALLEY, Pershing County, Nevada [abs.]: Ground Water, v. 21, no. 2, p. 222-223.

*Welch, A.H., Szabo, Zoltan, Parkhurst, D.L., Van Metre, P.C., and Mullin, A.H., 1993, A limitation of gross-beta activity in environmental studies of ground water [abs.]: 35th Rocky Mountain Conference on Analytical Chemistry, Society for Applied Spectroscopy and American Chemical Society, Denver, Colo., July 1993, Program and Abstracts, no. 314.

*Welch, A.H., Szabo, Zoltan, Parkhurst, D.L., Van Metre, P.C., and Mullin, A.H., 1993, A limitation of gross-beta activity in studies of naturally occurring beta-emitting radionuclides in ground water [abs.]: Eos, American Geophysical Union Transactions, v. 74, no. 43, p. 298.
Welch, A.H., and Thomas, J.M., 1984, Aqueous geochemistry and isotope hydrology of the WHITE RIVER system, eastern Nevada [abs.]: Geological Society of America, Abstracts with Programs, v. 16, no. 6, p. 689.

Welch, A.H., Thomas, J.T., and Gunderson, L.S., 1990, Distribution and sources of uranium in ground water in the CARSON RIVER BASIN, western Nevada and eastem California, U.S.A. [abs.]: Eos, American Geophysical Union Transactions, v. 71, no. 43, p. 1305.

Welch, A.H., and Williams, R.P., 1986, Data on groundwater quality for the MILLETT $1^{\circ} \times 2^{\circ}$ quadrangle, central Nevada: U.S. Geological Survey Open-File Report 85-648-A, one sheet.

Welch, A.H., and Williams, R.P., 1986, Data on groundwater quality for the ELKO $1^{\circ} \times 2^{\circ}$ quadrangle, eastern Nevada: U.S. Geological Survey Open-File Report 85 648-B, one sheet.

Welch, A.H., and Williams, R.P., 1986, Data on groundwater quality for the ELY $1^{\circ} \times 2^{\circ}$ quadrangle, eastern Nevada: U.S. Geological Survey Open-File Report 85648-C, one sheet.

Weich, A.H., and Williams, R.P., 1986, Data on groundwater quality for the LUND $1^{\circ} \times 2^{\circ}$ quadrangle, eastern Nevada: U.S. Geological Survey Open-File Report 85648-D, one sheet.

Welch, A.H., and Williams, R.P., 1987, Data on groundwater quality for the McDERMITT $1^{\circ} \times 2^{\circ}$ quadrangle, northern Nevada: U.S. Geological Survey OpenFile Report 85-648-E, one sheet.

Welch, A.H., and Williams, R.P., 1987, Data on groundwater quality for the LOVELOCK $1^{\circ} \times 2^{\circ}$ quadrangle, western Nevada: U.S. Geological Survey Open-File Report 85-648-F, one sheet.

Welch, A.H., and Williams, R.P., 1987, Data on groundwater quality for the WINNEMUCCA $1^{\circ} \times 2^{\circ}$ quadrangle, central Nevada: U.S. Geological Survey OpenFile Report 85-648-G, one sheet.

Welch, A.H., and Williams, R.P., 1987, Data on groundwater quality for the RENO $1^{\circ} \times 2^{\circ}$ quadrangle, western Nevada: U.S. Geological Survey Open-File Report 85-648-H, one sheet. 
Welch, A.H., and Williams, R.P., 1987, Data on groundwater quality for the WALKER LAKE $1^{\circ} \times 2^{\circ}$ quadrangle, western Nevada and eastern California: U.S. Geological Survey Open-File Report 85-648-I, one sheet.

Welch, A.H., and Williams, R.P., 1987, Data on groundwater quality for the TONOPAH $1^{\circ} \times 2^{\circ}$ quadrangle, central Nevada: U.S. Geological Survey Open-File Report 85-648-J, one sheet.

Welch, A.H., and Williams, R.P., 1987, Data on groundwater quality for the western Nevada part of the GOLDFIELD $1^{\circ}$ × $2^{\circ}$ quadrangle: U.S. Geological Survey Open-File Report 85-648-K, one sheet.

Welch, A.H., and Williams, R.P., 1987, Data on groundwater quality for the CALIENTE $1^{\circ} \times 2^{\circ}$ quadrangle, eastern Nevada: U.S. Geological Survey Open-File Report 85-648-L, one sheet.

Welch, A.H., and Williams, R.P., 1987, Data on groundwater quality for the western Nevada part of the DEATH VALLEY $1^{\circ} \times 2^{\circ}$ quadrangle: U.S. Geological Survey Open-File Report 85-648-M, one sheet.

Welch, A.H., and Williams, R.P., 1987, Data on groundwater quality for the southern Nevada part of the KINGMAN $1^{\circ} \times 2^{\circ}$ quadrangle: U.S. Geological Survey Open-File Report 85-648-N, one sheet.

*Westenburg, C.L., 1993, Water-resources data for the DEVILS HOLE AREA, Nye County, Nevada, July 1978-September 1988: U.S. Geological Survey OpenFile Report 90-381, 13 p.

Whitfield, M.S., Jr., Eshom, E.P., Thodarson, William, and Schaefer, D.H., 1985, Geohydrology of rocks penetrated by test well USW-H-4, YUCCA MOUNTAIN, Nye County, Nevada: U.S. Geological Survey WaterResources Investigations Report 85-4030, 33 p.

Whitney, J.W., Harrington, C.D., and Glancy, P.A., 1988, Deciphering Quaternary alluvial history in LAS VEGAS WASH, Nevada, by radiocarbon and rockvarnishing dating [abs.]: Geological Society of America, Abstracts with Programs, v. 20, no. 3, p. 243.

*Winograd, I.J., 1970, Noninstrumental factors affecting measurement of static water levels in deeply buried aquifers and aquitards, NEVADA TEST SITE: Ground Water, v. 8, no. 2, p. 19-28.
Winograd, I.J., and Eakin, T.E., 1965, Interbasin movement of ground water in SOUTH-CENTRAL NEVADAThe evidence, in Abstracts for 1964: Geological Society of America Special Paper 82, p. 227.

*Winograd, I.J., and Thordarson, William, 1975, Hydrogeologic and hydrochemical framework, SOUTHCENTRAL GREAT BASIN, Nevada-California, with special reference to the NEVADA TEST SITE: U.S. Geological Survey Professional Paper 712-C, 126 p.

Wood, D.B., 1979, Water-level changes associated with ground-water development in LAS VEGAS VALLEY, Nevada, March 1977 to March 1978: Nevada Division of Water Resources, Information Report 29, 38 p.

Wood, D.B., 1988, Water-level changes associated with ground-water development in LAS VEGAS VALLEY, Nevada, 1978-79: Nevada Division of Water Resources, Information Report 30, 34 p.

Wood, D.B., 1988, Water-level changes associated with ground-water development in LAS VEGAS VALLEY, Nevada, 1979-81: Nevada Division of Water Resources, Information Report 31, 41 p.

Wood, D.B., 1991, Water-level changes associated with ground-water withdrawals and surface-water imports, LAS VEGAS VALLEY, Nevada, 1981-83: Nevada Division of Water Resources, Information Report 32, $75 \mathrm{p}$.

Wood, D.B., 1991, Water-level changes associated with ground-water withdrawals and surface-water imports, LAS VEGAS VALLEY, Nevada, 1983-85: Nevada Division of Water Resources, Information Report 33, $70 \mathrm{p}$.

*Wood, D.B., 1992, Ground-water data collected at the NEVADA TEST SITE and vicinity, Nye County, Nevada, water years 1988-89: U.S. Geological Survey Open-File Report 92-130, 50 p.

*Wood, J.L., and Andraski, B.J., 1992, Selected meteorological data for an arid site near BEATTY, Nye County, Nevada, calendar year 1989: U.S. Geological Survey Open-File Report 92-484, 27 p.

Wood, J.L., and Fischer, J.M., 1991, Selected meteorological data for an arid site near BEATTY, Nye County, Nevada, calendar year 1986: U.S. Geological Survey Open-File Report 91-189, 27 p. 
*Wood, J.L., and Fischer, J.M., 1992, Selected meteorological data for an arid site near BEATTY, Nye County, Nevada, calendar year 1987: U.S. Geological Survey Open-File Report 92-59, 27 p.

*Wood, J.L., Hill, K.J., and Andraski, B.J., 1992, Selected meteorological data for an arid site near BEATTY, Nye County, Nevada, calendar year 1988: U.S. Geological Survey Open-File Report 92-61, 27 p.

Worts, G.F., Jr., 1963, Effect of ground-water development on the pool level in DEVILS HOLE, Death Valley National Monument, Nye County, Nevada: U.S. Geological Survey Open-File Report 63-142, 27 p.

Worts, G.F., Jr., 1963, Water supply for ELDORADO CANYON, Nelson's Landing and vicinity, Nevada: U.S. Geological Survey Open-File Report.

Worts, G.F., Jr., and Malmberg, G.T., 1966, Hydrologic appraisal of EAGLE VALLEY, Ormsby County, Nevada: Nevada Department of Conservation and Natural Resources, Water Resources - Reconnaissance Report 39, 55 p.

Zohdy, A.A.R., Bisdorf, R.J., and Glancy, P.A., 1977, Schlumberger resistivity soundings near FALLON, Nevada: Nevada Division of Water Resources, Information Report 25, 39 p.

Zones, C.P., 1957, Changes in hydrologic conditions in the DIXIE VALLEY and FAIRVIEW VALLEY areas, Nevada, after the earthquake of December 16, 1954: Seismological Society of America Bulletin, v. 47, no. 4, p. 387-396.

Zones, C.P., 1961, Ground-water reconnaissance of WINNEMUCCA LAKE VALLEY, Pershing and Washoe Counties, Nevada: U.S. Geological Survey Water-Supply Paper 1539-C, 18 p.

Zones, C.P., 1961, Ground-water potentialities in the CRESCENT VALLEY, Eureka and Lander Counties, Nevada: U.S. Geological Survey Water-Supply Paper $1581,50 \mathrm{p}$.

Zones, C.P., 1963, Ground water in the alluvium of KINGS RIVER VALLEY, Humboldt County, Nevada: U.S. Geological Survey Water-Supply Paper 1619-L, 38 p. 